Georgia State University

ScholarWorks @ Georgia State University

2013

\title{
Taxation and Inequality in the Americas: Changing the Fiscal Contract?
}

Richard M. Bird

University of Toronto, rbird@rotman.utoronto.ca

Eric M. Zolt

Follow this and additional works at: https://scholarworks.gsu.edu/icepp

Part of the Economics Commons

\section{Recommended Citation}

Bird, Richard M. and Zolt, Eric M., "Taxation and Inequality in the Americas: Changing the Fiscal Contract?" (2013). ICEPP Working Papers. 50.

https://scholarworks.gsu.edu/icepp/50

This Working Paper is brought to you for free and open access by the International Center for Public Policy at ScholarWorks @ Georgia State University. It has been accepted for inclusion in ICEPP Working Papers by an authorized administrator of ScholarWorks @ Georgia State University. For more information, please contact scholarworks@gsu.edu. 
INTERNATIONAL CENTER FOR PUBLIC POLICY
International Center for Public Policy Working Paper 13-15

May 2013

Taxation and Inequality in the Americas:

Changing the Fiscal Contract?

Richard M. Bird

Eric M. Zolt

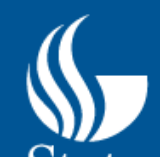

GeorgaState

ANDREWYOUNG SCHOOL

University

OF POLICY STUDIES 



\title{
International Center for Public Policy \\ Working Paper 13-15
}

\section{Taxation and Inequality in the Americas: Changing the Fiscal Contract?}

\author{
Richard M. Bird \\ Eric M. Zolt
}

May 2013

International Center for Public Policy

Andrew Young School of Policy Studies

Georgia State University

Atlanta, Georgia 30303

United States of America

Phone: (404) 651-1144

Fax: (404) 651-4449

Email: hseraphin@gsu.edu

Internet: http://aysps.gsu.edu/isp/index.html

Copyright 2006, the Andrew Young School of Policy Studies, Georgia State University. No part of the material protected by this copyright notice may be reproduced or utilized in any form or by any means without prior written permission from the copyright owner. 


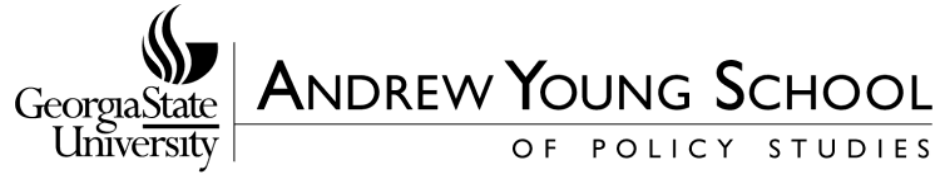

\section{International Center for Public Policy Andrew Young School of Policy Studies}

The Andrew Young School of Policy Studies was established at Georgia State University with the objective of promoting excellence in the design, implementation, and evaluation of public policy. In addition to two academic departments (economics and public administration), the Andrew Young School houses seven leading research centers and policy programs, including the International Center for Public Policy.

The mission of the International Center for Public Policy is to provide academic and professional training, applied research, and technical assistance in support of sound public policy and sustainable economic growth in developing and transitional economies.

The International Center for Public Policy at the Andrew Young School of Policy Studies is recognized worldwide for its efforts in support of economic and public policy reforms through technical assistance and training around the world. This reputation has been built serving a diverse client base, including the World Bank, the U.S. Agency for International Development (USAID), the United Nations Development Programme (UNDP), finance ministries, government organizations, legislative bodies and private sector institutions.

The success of the International Center for Public Policy reflects the breadth and depth of the in-house technical expertise that the International Center for Public Policy can draw upon. The Andrew Young School's faculty are leading experts in economics and public policy and have authored books, published in major academic and technical journals, and have extensive experience in designing and implementing technical assistance and training programs. Andrew Young School faculty have been active in policy reform in over 40 countries around the world. Our technical assistance strategy is not to merely provide technical prescriptions for policy reform, but to engage in a collaborative effort with the host government and donor agency to identify and analyze the issues at hand, arrive at policy solutions and implement reforms.

The International Center for Public Policy specializes in four broad policy areas:

- Fiscal policy, including tax reforms, public expenditure reviews, tax administration reform

- Fiscal decentralization, including fiscal decentralization reforms, design of intergovernmental transfer systems, urban government finance

- Budgeting and fiscal management, including local government budgeting, performancebased budgeting, capital budgeting, multi-year budgeting

- Economic analysis and revenue forecasting, including micro-simulation, time series forecasting,

For more information about our technical assistance activities and training programs, please visit our website at http://aysps.gsu.edu/isp/index.html or contact us by email at hseraphin@gsu.edu. 


\title{
Taxation and Inequality in the Americas: Changing the Fiscal Contract?
}

\author{
Richard M. Bird \\ University of Toronto \\ Eric M. Zolt \\ University of California, Los Angeles
}

There is a tide in the affairs of men Which, taken at the flood, leads on to fortune,

Omitted, all the voyage of their life Is bound in shallows and in miseries. (Shakespeare, Julius Caesar, 4: 218-222)

Times change. In the words of an old English ballad, some things seem to have "turned upside down" in recent years. Since 2000, Latin America has become less unequal, with lower levels of poverty and likely greater economic mobility (Lustig, Lopez-Calvo and Ortiz-Juarez 2012), assisted in part by more progressive fiscal policy (Mahon 2012). In contrast, the United States has become more unequal (Piketty and Saez 2003, 2013), while poverty has remained relatively constant (U.S. Census Bureau 2012), economic mobility has likely declined (Hungerford 2008), and tax and spending policies have become less effective in reducing inequality (Harris and Sammartino 2011).

This chapter examines whether the tide has really changed in Latin America or in the United States, and, if it has, what may lie ahead for these two regions of the Americas? Do recent events portend fortune or misery? Although the primary cause of the more equal income distribution in Latin America is probably the sharp increase in growth and employment following the challenging political and economic decade of the 1990s (Gasparini and Lustig 2011), fiscal policy played at least some role. Indeed, recent Latin American experience suggests that the pessimism prevalent since the 1970s about the extent to which taxation can affect income distribution has perhaps been misguided. Economic, social and political changes can and do give rise to new norms and power configurations, which sometimes result in important changes in the social and fiscal contract underlying governance structures. 


\section{Setting the Stage}

As a region, Latin America has long led the world in terms of income inequality (Blofield 2011). Latin American fiscal policy, especially tax policy, did little to remedy this state of affairs (Mahon 2011). In contrast, the United States has been viewed not only as a land of opportunity, where hard work, thrift and personal responsibility lead to economic reward but also as a country in which taxes are more progressive than in most other countries. The story of development in the Americas over the last century seems broadly to support this tale, with regions with higher levels of inequality adopting fiscal policies that result in lower tax revenues and lower levels of social spending than regions with lower levels of inequality (Sokoloff and Zolt 2006). From time to time, however, divergences from these broad trends have occurred. One such divergence has been in the last decade or so.

Although experiences in Latin America have been as varied as the countries of the region, Lopez-Calva and Lustig (2010) show that the story of recent developments is both economic and political. Economic growth has produced more jobs and better jobs and hence a less unequal pre-tax (market-generated) distribution of income, with an expanding middle class and an increasing income tax base. ${ }^{1}$ Although taxes have not become much more progressive, in some countries transfers have done so, resulting in poverty being reduced in both relative and absolute terms. ${ }^{2}$ While no Latin American country has yet managed to tax the rich very effectively and the long-term sustainability of recent trends is far from certain, these recent trends are very different than those widely predicted only a few years ago.

The story in the United States over the same time period also differs from the long-term picture set forth above. Recent economic developments have resulted in increased inequality, no reduction in poverty levels, and increased vulnerability for the middle class. Although federal income tax rates have been reduced for everyone (especially the middle class and the poor), the top quintile (especially the top 1 percent) has become so wealthy that the share of tax revenues from personal income taxes remains high (OECD 2012) and the total federal tax burden has been relatively constant over the last 60 years averaging around 18 percent of GDP (JCT 2012). On the other side of the budget, although levels of social spending have increased, a greater proportion is going to the elderly (without regard to need)

\footnotetext{
${ }^{1}$ In a recent detailed analysis, Azevedo et al. (2013) show that the decrease in inequality in the region has been driven largely by changes in labor income reflecting both improved levels of education and demographic factors, although they caution that more investment in the right kind of education and training is needed to sustain recent trends.

${ }^{2}$ As Lustig and Higgins (2012) show with respect to Brazil, however, even when taxes and transfers have significant effects on poverty and inequality, not every 'poor' or 'non-poor' group is likely to be affected in the same way.
} 
than to the poor (Harris and Sammartino 2011). There is also concern about a shrinking and declining middle class. A recent study notes that since 2000, "the middle class has shrunk in size, fallen backward in income and wealth, and shed some-but by no means all-of its characteristic faith in the future" (Pew Research Center 2012). ${ }^{3}$ From a high of $\$ 152,950$ in 2007, median household wealth in the United States fell to $\$ 93,150$ in 2010, up only slightly from the 1983 level of $\$ 91,506$ (Pew Center 2012).

One lesson that emerges from both these cases is that government tax and spending policies continue to be important factors affecting inequality. Prominent experts take widely divergent views on what the effects of current policies, or potential changes in policy, might be for different countries. Compare, for example, two recent reviews of the Mirrlees (2011) report on the reform of the British tax system. Except for a few surprisingly positive words supporting wealth taxes, Feldstein (2012), clearly thinking mainly of the American case, emphasizes what might be called the 'new economic orthodoxy' of the costs of taxation in terms of growth, as well as taxation's ineffectiveness as a redistributive tool. ${ }^{4}$ On the other hand, Atkinson (2012), writing from a British perspective, provides a much more nuanced and comprehensive view of the nature and impact of appropriate tax policy in a modern democracy. This broader approach is more helpful in understanding recent fiscal developments in many Latin American countries, and may also have something to contribute to the ongoing debates in the United States. ${ }^{5}$

The question of the effects of tax policies in the United States and Latin America on inequality is particularly interesting because of the contrast between the tax systems of the two regions. The United States has long been a country that relies heavily on personal income taxes to finance the federal government; it is also one of the few countries in the world to have no national general sales tax. In contrast, Latin America has long relied on consumption taxes (particularly the value-added tax (VAT) and excise taxes) and most countries make very little use of personal income taxes. Whether either region can maintain these patterns in the face of recent changes in inequality is uncertain.

Is the United States becoming more like Latin America? The increasing concentration of income at the top, persistent levels of poverty, declining economic mobility, and declining public services may suggest

\footnotetext{
${ }^{3}$ Because almost every study, survey and commentator seems to have a different definition of the 'middle class' (for examples, see Banerjee and Duflo (2008), Lora and Fajardo (2011), and Atkinson and Brandolini (2011)), it is not possible here to either examine the details of the different classification approaches found in different studies or consider the implications of these differences for cross-national comparisons.

${ }^{4}$ In an earlier discussion of these issues, we also emphasized the latter point in the context of developing countries (Bird and Zolt 2005).

${ }^{5}$ For three quite different contributions of the U.S. discussion, see Zolt (2013), Kleinbard (2012) and Roemer (2011).
} 
that the answer is "yes." Inequality has reached levels not seen since the 1920s, and the gap between the haves and the have-nots with respect to equality of opportunities for quality education and academic achievement continues to grow (Reardon 2011). Fiscal challenges and tax competition may, in the end, break the United States' heavy dependence on the federal personal income tax and result in the introduction of a VAT or some other type of broad-based consumption tax. However, whatever happens in the next decade or so, the United States will not morph into Sweden. The size of government is unlikely to expand greatly, and the federal tax system is likely to continue to be dominated by the personal income tax, even if some form of VAT is adopted.

Is Latin America likely to emulate the United States in following the small government model with relatively low levels of public social spending? Or will different countries in the region go different ways, with some continuing to be relatively small welfare states (such as Mexico) and others moving over time to a more European approach with relatively larger welfare states (such as Brazil)? Even countries that follow the first approach may nonetheless continue to expand their social spending, in part for political stability reasons. However, any such expansion of the public sector will likely be financed mainly by the VAT rather than the personal income tax. Countries that follow the European model are also likely to rely most heavily on the VAT, although increasingly supported by revenues from a more robust income tax system. ${ }^{6}$ In both cases, most new tax revenue will have to come from not only the wealthy, but also the increasingly important middle class. To be able to implement and sustain such tax changes, countries may have to strengthen the 'Wicksellian connection' between taxes and spending (Breton 1996) by matching tax increases to more universalist social programs encompassing a broader swathe of society, as opposed to the targeted (poverty-oriented) conditional cash programs recently adopted in both Brazil and Mexico.

\section{Inequality, Poverty, and Economic Mobility}

Countries differ in the priorities attached to such related but distinct objectives as reducing inequality, reducing poverty, and increasing economic mobility. Moreover, such priorities may change over time. In this and the next section, we present a brief summary of the complex story of the interplay between

\footnotetext{
${ }^{6}$ In an interesting analysis of fiscal redistribution in Latin America, Barreix, Roca and Villela (2007) emphasize the need to strengthen (and make more progressive) both these pillars of the tax system. However, on the spending side, they urge still more targeting of expenditures on distributive grounds rather than the 'universalist' expansion to include significant benefits to the middle class we suggest may be required.
} 
taxation and inequality in the Americas. We focus largely on the extent and ways in which taxes affect redistribution between three groups: the 'rich' (the top end of the income distribution, defined differently in different contexts depending largely on the data), the 'poor' (the bottom 40 percent or so) and the huge and varied group in between these extremes that we call, for want of a better word, 'the middle. $^{7}$

\section{The distribution of income}

The most common summary measure of income inequality is the Gini coefficient, with a higher number representing greater inequality. Table 1 shows Gini coefficients for income inequality for the last 40 years for five major countries in Latin America, as well as for the United States and Canada. ${ }^{8}$ Income distribution clearly remains far more unequal south of the border. Over the last 40 years, however, the average Gini coefficient rose by only about 4 percent in the five Latin American countries compared to a much greater increase in inequality in North America (12 percent). Especially striking is the decline in the Gini coefficients in the Latin American countries from an average of .56 in 2000 to .52 at the end of the decade, compared to the continued increase in the Gini coefficient for the United States over the same period. As Lustig, Lopez-Calvo and Ortiz-Juarez (2012) report for Latin America as a whole, the unweighted regional Gini coefficient (for household per capita income) declined from .53 in the late 1990 s to .50 in 2010, with 12 of the 17 countries for which reasonably comparable data are available showing a statistically significant decline. ${ }^{9}$

\footnotetext{
${ }^{7}$ Although we broadly adopt the 'fiscal contract' view of the state set out by North and Weingast (1989) and developed further by Timmons (2005) and others, many discussions that take a similar approach at least implicitly limit the analysis by either focusing on only two groups, rich and poor (e.g. Ardanaz and Scartascini 2011) or by essentially ignoring the critical link between the two sides of the budget (e.g. Hart 2010). In contrast, our focus here is specifically on the critical changes in the middle class that may explain much of what has happened in many countries as well as the possible implications of these changes for both sides of the budget.

${ }^{8}$ There are a number of ways to measure Gini coefficients, see http://website1.wider.unu.edu/wiid/WIID2c.pdf as well as Goni, Lopez and Serven (2008). Although the measures shown in Table 1 do not all refer to exactly the same concepts in all countries at all periods, for the most part they are based on household estimates (in per capita terms) of disposable income, that is, gross money income less direct taxes plus direct transfers (Goni, Lopez and Serven 2008). The coefficients in Table 1 appear to provide about as good a set of numbers as exist to make broad comparisons between countries over this time period.

${ }^{9}$ How much inequality has changed depends on not only what is measured but for whom it is measured. The data in Table 1 (and Table 2) are at the household level (in per capita terms). Data on individuals emphasize changes in labor income and wage differentials, but data on households better measure the economic well-being of individuals living together. Some consider that measures based on relative changes in consumption would provide a better indication of actual welfare. Duncan and Peter (2012) in a recent interesting analysis suggest that, if properly measured, reduced tax progressivity in countries with high levels of evasion may actually improve welfare as measured by the consumption Gini even if such changes may appear to increase the Gini for observed income.
} 
Table 1. The Distribution of Income: Gini Coefficients

\begin{tabular}{|l|l|l|l|l|l|}
\hline Country & $\mathbf{1 9 7 0}$ & $\mathbf{1 9 8 0}$ & $\mathbf{1 9 9 0}$ & $\mathbf{2 0 0 0}$ & $\mathbf{2 0 1 0}$ \\
\hline Argentina & .36 & .41 & .50 & .54 & .51 \\
\hline Brazil & .58 & .60 & .63 & .64 & .56 \\
\hline Colombia & .43 & .53 & .53 & .57 & .56 \\
\hline Mexico & .54 & .50 & .54 & .54 & .49 \\
\hline Peru & .56 & .57 & .51 & .53 & .46 \\
\hline United States & .32 & .34 & .35 & .36 & .38 \\
\hline Canada & .30 & .30 & .29 & .32 & .32 \\
\hline
\end{tabular}

Sources: For Latin America: Gini coefficients for earlier years from WIDER http://www.wider.unu.edu/research/Database/en GB/wiid/ and since 1990 from CEPAL http://websie.eclac.cl/sisgen/Consultalntegrada.asp ; coefficient shown is for year nearest date indicated and coverage varies from country to country (e.g. only urban sector for Argentina). For North America: Gini coefficients from stats.oecd.org (for mid-decade in 1970s and 1980s and for late 2000s for last column). Although every effort has been made to make the data as comparable in coverage, concept and year as possible, there are wide variations from country to country and over time even within particular countries. Details of data concepts and sources may be found in the sources indicated.

There are many different ways to measure income inequality. Table 2 sets out several different measures of changes in income distribution in Latin America over the last two decades. Over this period, the share of income going to the top 10 percent of the population declined sharply in Brazil, Mexico and Peru, but remained almost unchanged in Argentina and increased in Colombia. While the ratio of per capita income in the top decile to that in the bottom four deciles rose slightly in Argentina and Colombia, it declined significantly in the other three countries. Finally, in all five countries the share of the population living below the poverty line declined sharply. In summary, it seems clear that on the whole, income inequality and especially poverty decreased sharply in recent years, particularly in Brazil, Mexico and Peru. This is also true for Argentina and Colombia, at least in terms of poverty reduction.

In contrast, in the United States, between 1979 and 2007, households at the very top of the income distribution experienced by far the largest gains in both relative and absolute income, with the pre-tax income of the top 1 percent almost tripling in this period (Harris and Sammartino 2011). Over the last three decades, the income of households in the top quintile (not including the top 1 percent) increased by 65 percent, while income growth was 40 percent for the middle three quintiles and only 18 percent

This approach, which reduces the apparent equity costs of more efficient taxes, lends some support to the case for dual income taxes in developing countries made in Bird and Zolt (2011). As noted there, an argument for adopting this approach to broadening the income tax base and making it more effectively progressive was made earlier by Barreix and Roca (2007) in a study of Uruguay. Subsequently, Barreix, Bes and Roca (2010) extended the argument to Latin America more generally. 
for the lowest quintile. In other words, the rich got richer, and the middle class and the poor, while better off in absolute terms, became relatively worse off. In contrast, in the five Latin American countries over the last two decades, the share of the top decile decreased by 9 percent, the share of the second and third quintiles increased by 6 percent, and the share of the bottom 40 percent (the poor) increased by 9 percent. ${ }^{10}$

Table 2. Income Inequality and Poverty in Latin America, 1990-2010

\begin{tabular}{|r|c|c|c|}
\hline \multicolumn{1}{|c|}{ Country and Year } & $\begin{array}{c}\text { Share of Personal } \\
\text { income } \\
\text { going to top Decile }\end{array}$ & $\begin{array}{c}\text { Ratio of per capita } \\
\text { Income in top decile } \\
\text { to that in bottom 40 } \\
\text { percent }\end{array}$ & $\begin{array}{c}\text { Share of } \\
\text { population } \\
\text { Living below } \\
\text { Poverty line }\end{array}$ \\
\hline Argentina 1990 & 39.4 & 13.5 & 16.1 \\
\hline 2000 & 42.8 & 16.6 & 23.7 \\
\hline 2010 & 39.8 & 15.1 & 8.6 \\
\hline Brazil 1990 & 50.6 & 31.2 & 48.0 \\
\hline 2000 & 53.0 & 31.9 & 37.5 \\
\hline 2010 & 45.0 & 21.1 & 24.9 \\
\hline Colombia 1990 & 42.6 & 16.7 & 56.1 \\
\hline 2000 & 46.4 & 22.3 & 54.9 \\
\hline 2010 & 44.0 & 20.1 & 37.3 \\
\hline Mexico 1990 & 43.8 & 17.2 & 47.7 \\
\hline 2000 & 43.2 & 17.9 & 36.3 \\
\hline Peru 1990 & 37.4 & 12.8 & n.a. \\
\hline 2000 & n.a & n.a. & 48.6 \\
\hline 2010 & 43.6 & 19.5 & 31.3 \\
\hline Average Change & 34.6 & 11.4 & $-33.7 \%$ \\
\hline $2010 / 1990$ & $-8.8 \%$ & $+2.4 \%$ & \\
\hline
\end{tabular}

Source: CEPAL http://websie.eclac.cl/sisgen/Consultalntegrada.asp; Argentina for urban only; for years closest to those indicated. As indicated for Table 1, although we have tried to be as comparable as possible over both countries and time, at best this table should be considered only an approximation, and other numbers may often be found in other sources for what seem to be the same concept: for more detailed information on the data, see the source cited.

While growing income inequality is troubling, even more disturbing may be the high levels of wealth inequality in the United States. In all countries, wealth is more concentrated than income (Wolff 1996). Over the last 50 years, the Gini coefficient for wealth distribution in the United States has increased

\footnotetext{
${ }^{10}$ Calculated from data in http://websie.eclac.cl/sisgen/Consultalntegrada.asp.
} 
from .80 in 1962 to .87 in 2010 (Wolff 2012). ${ }^{11}$ While wealth distribution data are even harder to assemble and compare than income distribution data, as Table 3 shows, the Gini coefficient for wealth distribution in $\mathbf{2 0 0 0}$ was even higher in the United States than in the three Latin American countries for which data were available, and markedly higher than that in Canada. ${ }^{12}$

Table 3. The Distribution of Wealth: Gini Coefficients, 2000

\begin{tabular}{|l|l|}
\hline Country & Gini \\
\hline Argentina & .74 \\
\hline Brazil & .76 \\
\hline Mexico & .78 \\
\hline United States & .80 \\
\hline Canada & .69 \\
\hline
\end{tabular}

Source: Estimates based on purchasing power parity exchange rates from Davies et al. (2008)

\section{Intra-generational and inter-generational economic mobility}

Income equality appears to be linked to social mobility largely through its effects on the extent to which people have equal access to opportunities for improvement rather than on its direct effects on individual effort (Brunori, Ferreira, and Pangini 2013). There are two major approaches to examining economic mobility. Intra-generational mobility focuses on the individual to determine how much his or her absolute or relative position has improved over time compared with the general population. Intergenerational mobility measures seek to estimate how much of a child's income can be attributable to his or her parent's income.

Ferreira et al. (2013) find that the impressive change in income distribution in Latin America over the last decade or so has resulted in a substantial expansion of the middle class (which they define as those with income, at purchasing power parity exchange rates, of between USD 10 and USD 50 per person per day) from 20 to 30 percent of the population. Although an annual per capita income of $\$ 3650$ may not sound like much to North Americans, Ferreira et al. (2013) suggest that it is sufficient to provide both a

\footnotetext{
${ }^{11}$ Excluding personal residences, the concentration of wealth has increased from .84 in 1962 to .93 in 2010 (Wolff 2012). As with income there are different ways of measuring wealth distribution, which may often yield different results. For a comprehensive discussion, see Davies (2008).

${ }^{12}$ As Torche and Spilerman (2008) show, however, land ownership is much more concentrated in Latin America than in the United States.
} 
basic middle class standard of living and some degree of resilience to economic shocks. The fact that the fraction of the regional population reaching this level increased by 50 percent in little more than a decade is a remarkable achievement. Of course, there are still a great many poor people in Latin America. 68 percent of the regional population lived below the middle class level (as defined above) in 2009 compared to about 78 percent in 1995. And 30 percent were still classified as poor (with incomes of less than USD 4 per day) in 2009 compared to 44 percent in 1995. Few people move from poverty to middle class within a few years. Most who exited the 'poor' category instead moved into what Ferreira et al (2013) call the 'vulnerable' class, with an income between $\$ 4$ and $\$ 10$ a day, an amount that is decidedly better than poverty but not enough for comfort. This vulnerable group (which grew from 34 percent in 1995 to 38 percent in 2009) is now the largest group in Latin America. Although the absolute size of the vulnerable group has remained relatively constant, its composition changed substantially over this period, as many who were vulnerable 15 years ago moved to the middle class and were replaced by others who were formerly poor.

Ferreira et al. (2013) thus document a surprising degree of intra-generational income mobility in Latin America in recent years. However, Table 4 suggests that inter-generational income mobility, as defined by the incomes of children compared to those of their parents, has not experienced the same change: inter-generational mobility remains considerably less in Peru and Brazil than in the United States, although the gap between Argentina and the United States is smaller. ${ }^{13}$ While a few European countries, such as the United Kingdom and Italy, have economic mobility levels comparable to that of the United States, most European countries have inter-generational income mobility levels much closer to Canada than to either the United States or Latin America (Corak 2012). The higher the intergenerational income elasticity, the more likely it is that the children of high-income parents will also have higher incomes. For example, in Peru, if one father makes 100 percent more than another, then the son of the first is likely to earn about 70 percent more than the son of the second. In the US (and

\footnotetext{
${ }^{13}$ As with income inequality, however, there are many ways to measure income mobility and different measures may give very different results. Measuring income persistence across a single generation may not be the best measure of inter-generational income mobility (see Jantti et al. 2006). The measures reported in Table 4, however, are the only ones available for many Latin American countries; moreover, other studies, such as that just cited, which employ different measures, show comparable results when comparing the United States to European countries. On the other hand, Clark (2013), using a quite different approach (based on surnames) estimates both that the rate of social mobility in the United States is no lower than in other countries and that it has not declined in recent years. And in a recent study, Krebs, Krishna and Maloney (2013) find that most estimates of income mobility in Mexico are subject to measurement error or transitory income shocks and likely provide little evidence of economically significant effects. As with all other aspects of assessing inequality, there is still much to be learned both about how to measure social mobility and how to interpret the results.
} 
Argentina), the son of the richer parent is likely to earn about 50 percent more, and in Canada (and northern Europe), the son of the richer parent will earn only 20 percent more.

Table 4. Economic Mobility across Generations

$\begin{array}{ll}\text { Argentina } & .49 \\ \text { Brazil } & .58 \\ \text { Chile } & .52 \\ \text { Peru } & .67 \\ \text { United States } & .47 \\ \text { Canada } & .19\end{array}$

Source and notes: The number reported is the 'inter-generational elasticity of earnings' as measured by the percentage difference in the share of the child's earning associated with the percentage difference in the parent's earnings from Corak (2012)

To sum up, the degree of economic mobility in Latin America and the United States, at least when measured in these terms, appears to be substantially less than economic mobility in either Canada or Europe. American 'exceptionalism' in terms of actual levels of economic mobility may be substantially less than perceived levels.

Access to quality education is a major factor in explaining differences in economic mobility across generations and among countries. Here, the United States and Latin America have had historically different traditions in providing public education, with the United States being a world leader in providing first common school and later high school and university education (Goldin and Katz 2008), and Latin American countries long being less willing to support public education (Engerman and Sokoloff 2001). In recent years, the academic achievement gap between the rich and the poor in the United States has widened substantially (Reardon 2011). In contrast, some Latin American countries, although still notably unequal in terms of access to quality education, have made substantial progress in improving the position and educational attainment of previously disadvantaged groups (OECD 2012c), as well as in improving the quality of education by international standards. ${ }^{14}$ These developments, if continued, will lead to a decrease in economic mobility in the United States and an increase in economic mobility in Latin America.

\footnotetext{
${ }^{14}$ On the latter point, see the analysis of PISA data in Ferreira et al. (2013) as well as http://en.wikipedia.org/wiki/Programme for_International_Student_Assessment\#2000.E2.80.932006.
} 
The Impact of the Fiscal System

Although income in Latin America remains highly unequally distributed, there has been considerable improvement in a remarkably short time. Although two-thirds of this improvement, and three-quarters of the rise of the middle class (as defined in Ferreira et al. 2013), is attributable to the rise in average incomes with economic growth rather than to the decline of income inequality, explicit redistributive policies, especially the expansion of more targeted social spending, were important in several Latin American countries.

\section{Social spending}

Table 5 highlights the substantial increase in social spending in Latin America in recent years. ${ }^{15}$ Much of the increase is attributable to increases in social security spending (most notably in Colombia and Mexico). Perhaps surprisingly, despite the apparently improving outcomes in education mentioned earlier, the share of social spending going to education actually declined in many Latin American countries. This decline may not have had a particularly adverse effect on inequality because a large portion of public educational spending in many countries primarily benefits higher income groups due to the combination of free (or low cost) tertiary education with the much higher percentage of largely privately educated higher-income children qualifying for university education. On the other hand, Canavire-Bacarreza, Martinez-Vazquez and Vulovic (2012) estimate that increased public expenditure on education may not only increase economic growth but significantly reduce income inequality.

Table 5. Social Spending in Latin America, Selected Years, 1990-2008 (as percent GDP)

\begin{tabular}{|c|c|c|c|c|c|}
\hline Country & $\mathbf{1 9 9 0}$ & $\mathbf{2 0 0 8}$ & $\begin{array}{c}\text { Percentage } \\
\text { Increase } \\
\text { Over } \\
\text { Period }\end{array}$ & $\begin{array}{c}\text { Education } \\
\text { As Percent } \\
\text { Social } \\
\text { Spending } \\
\mathbf{2 0 0 8}\end{array}$ & $\begin{array}{c}\text { Social Security } \\
\text { As Percent } \\
\text { Social } \\
\text { Spending } \\
\mathbf{2 0 0 8}\end{array}$ \\
\hline Argentina & 18.6 & 24.0 & 29 & 24.9 & 46.1 \\
\hline Brazil & 17.6 & 24.8 & 41 & 21.9 & 51.6 \\
\hline Colombia & 6.4 & 12.6 & 97 & 22.3 & 55.8 \\
\hline Mexico & 5.5 & 10.0 & 82 & 35.6 & 26.4 \\
\hline Peru & 4.0 & 8.7 & 118 & 32.1 & 35.1 \\
\hline
\end{tabular}

Source and Notes: Data from http://websie.eclac.cl/sisgen/Consultalntegrada.asp. Central government only for Colombia and Peru. Figures for Mexico are probably underestimated owing to difficulty in estimating some

\footnotetext{
${ }^{15}$ A similar rising trend is shown for social spending per capita, especially in Argentina, in Afonso et al. (2012) who use essentially the same data set as Table 5 .
} 
subnational expenditures. Social spending includes public sector expenditure on education, health and nutrition, social security, employment, social welfare, housing, and water and sewerage.

On the whole, social spending appears to have contributed to reducing income inequality in Latin America in recent years. In Brazil and Mexico, for example, cash transfer policies accounted for about 20 percent of the decline in inequality (Ferreira et al. 2013), while in Colombia an educational voucher scheme allowing students from poorer families to attend better schools appears to have had significant effects in improving educational outcomes (Angrist et al. 2002). Other studies in both Colombia and Chile summarized in Ferreira et al. (2013) demonstrate the possible gains from such innovations and reinforce the notion that one important way forward for Latin America may lie in reducing the fragmentation of the existing social contract by increasing the inclusivity of such key public institutions as schools.

An important outcome of extending and improving the quantity and quality of such critical public services may be to encourage the expanding middle class to buy into the expansion of the state sector rather than following the well-established path of the wealthy and opting out. An important factor explaining Latin America's historically high degree of inequality has been persistent inequity in access to education combined with poorly designed public social insurance transfers (de Ferranti 2004). Better educational opportunities for the children of the emerging middle class was one of the main drivers in building local and state capacity in North America in the $19^{\text {th }}$ and the first half of the $20^{\text {th }}$ century (Sokoloff and Zolt 2006). Especially in regions with greater equality, local governments were successful in expanding their fiscal base to provide more and better local goods and services. In Latin America, however, the wealthy have long avoided public health and education services in favor of costlier, yet higher quality private services. Using the terms made familiar by Hirschman (1970), this 'exit' of much of the politically articulate population from public services has, importantly, meant that their 'voice' has not been heard with respect to the need for improving public services. However, with greater prosperity, more democracy, and increased decentralization (Brosio and Jimenez 2012), it may now be possible in some countries to establish a similar link between what people are willing to pay for and what they receive from the public sector.

Most Latin American countries supply some important services at two levels - private and public - for education, as mentioned above, and at three levels - private, social security, and public - for health, with public provision clearly being at the lower end of the quality spectrum in both types of services. Social security in much of Latin America, as in the United States, is concerned as much or more with 
financing health care as with financing government-provided pensions. ${ }^{16}$ Some countries in Latin America, such as Argentina, Brazil and Chile, introduced traditional compulsory social insurance schemes financed by payroll taxes even before World War II, like the United States. Others, including Colombia, Mexico, and Peru, followed in the 1950s, with late-comers like most of the Central American countries adopting social insurance programs in the 1960s and 1970s (Mesa-Lago 2008). The coverage and benefits of these schemes varies considerably from country to country, but in all cases, the social insurance system is financed through payroll taxes. On average, the level of these payroll tax rates in 2011 was over 20 percent, compared to the 17.35 percent in the United States, although with wide variation from country to country, ranging from 10.6 percent in Mexico to 45.148 percent in Colombia. Social security taxes are applied only in the formal sector of the economy. Similarly, the benefits from the social programs financed by these taxes (which include both pensions and health services) may generally be claimed only by those who are or have been employed in the formal sector and have therefore contributed to funding the programs, although there is often no tight connection between taxes paid and benefits received (Social Security Administration 2012).

Many consider the basic social insurance systems in most Latin American countries to be deeply flawed, given their limited coverage of only the formal sector, the marked evasion even within that sector, and the fact that transfers are regressive in that they do not go to the poor. Indeed, a careful study of social transfers in eight Latin American countries (including the five on which we focus here) concluded that the existing social system is in general both "grossly inefficient and regressive" (Lindert, Skoufias and Shapiro 2006, 4), with the partial exception of some of the conditional cash transfer systems mentioned above. Goni, Lopez and Serven (2008) estimate that about 70 percent of direct transfers go to the two top income quintiles in Latin America, compared to only about 40 percent in Europe, although taking inkind transfers into account redressed the balance to a considerable extent .

Lindert, Skoufias and Shapiro (2006) conclude that governments in Latin America need to take a more integrated and targeted approach to 'social protection,' a term encompassing both social insurance and social assistance. However, they recognize it is unlikely that such recommendations can or will be soon implemented since "...there is clearly some barrier to lowering social insurance transfers (even where

\footnotetext{
${ }^{16}$ In 2009, for example, social insurance accounted for 86.4 percent of government expenditure on health in the U.S. (a big increase from the 33.5 percent in 2000) compared to 59.4 percent in Argentina, 54.6 percent in Mexico, 48.6 percent in Colombia and 44.5 percent in Peru. In Canada, however, less than 2 percent of government expenditure on health was financed by social security and in Brazil none was (WHO 2012).
} 
they are highly inequitable) and raising social assistance transfers (even where they are progressive) in many countries...." (p.45). They note that such barriers likely arise from the different political constituencies served by these two classes of transfers, as well as the possible perceived legitimacy conferred on social insurance programs (because they link benefits to contributions, even if only partially) and on conditional cash transfers (because beneficiaries have to comply with a set of "coresponsibilities," e.g. sending their children to school). However, they do not consider, as the fiscal contract perspective developed below would suggest, that the demonstrated political sustainability of the existing policies may require extending such "islands of success" in ways that will encourage those who will have to pay more to think they get something valuable for their money, even if that money flows to others. Instead, like most experts, Lindert, Skoufias and Shapiro (2006) recommend adopting a tidy integrated social protection package, even though experience suggests such policies are only likely to be implemented successfully in homogeneous and highly developed societies very different than those in most of Latin America.

In recent years, the United States has also seen major changes to its public social spending policies. The share of the (politically popular) federal transfers going to the elderly rose over the last 30 years, from 62 percent in 1979 to 68 percent in 2007 (Harris and Sammartino 2011). One result of this change in funding priorities is that the effectiveness of fiscal policies in reducing inequality has declined because transfers to the elderly are not conditioned on income. ${ }^{17}$ For example, in 1979, households in the bottom quintile received over 54 percent of transfer payments, but by 2007 their share had declined to only 35 percent (Harris and Sammartino 2011).

Redistributive government spending can take the form not only of direct subsidies but also 'tax expenditures,' which tend to be distributed even less equitably. In the United States, for example, the top two quintiles receive about two-thirds of the benefits from tax expenditures for health care expenses and over 90 percent of the benefits from tax expenditures for incentives for retirement savings and home ownership, although the middle income groups also receive some benefits from these tax subsidies (Toder, Harris, and Lim 2009).

\footnotetext{
${ }^{17}$ Interestingly, a significant share of transfers to the elderly in Canada are income-conditioned, which, along with the slightly larger (VAT-financed) size of the state, may explain why fiscal redistribution is more important in Canada than in the United States (Bird and Zolt, forthcoming).
} 
As Table 6 shows, while tax expenditures, particularly with respect to income taxes, are much less important in Latin America than in North America, their effect on distribution may not be all that different, although no estimates of their distributive effect appear to exist.

Table 6. Tax Expenditures in the Americas, 2007

(as percent GDP)

\begin{tabular}{|c|c|c|c|}
\hline Country & Total & $\begin{array}{c}\text { Income } \\
\text { Tax } \\
\text { Subsidies }\end{array}$ & $\begin{array}{c}\text { VAT } \\
\text { Subsidies }\end{array}$ \\
\hline Argentina & 2.2 & 0.5 & 1.1 \\
\hline Brazil & 2.0 & 1.0 & 0.4 \\
\hline Colombia & 3.7 & 1.6 & 1.9 \\
\hline Mexico & 5.6 & 3.1 & 1.9 \\
\hline Peru & 2.2 & n.a. & n.a. \\
\hline Average & 3.1 & n.a. & n.a. \\
\hline Canada & 11.0 & 6.5 & 3.5 \\
\hline United States & 6.0 & 5.1 & n.a. \\
\hline
\end{tabular}

Source: For Latin America, Villela, Lemgruber and Jorratt (2010; for North America, OECD (2010).

\section{Taxation}

Table 7 summarizes a few key quantitative facts about taxation in the larger Latin American countries as well as the United States and Canada. In most Latin American countries, both tax ratios and the share of taxes coming from income taxation grew significantly over the last decade, in contrast to the decline in both ratios in North America. On the other hand, as the last column in Table7 shows, a major difference between North and South America is the dominant role of the personal income tax in the North and the dominant role of the corporate income tax in the South. This key structural feature of the tax system did not change significantly in Latin America, although both corporate and personal income tax rates fell over this period in most countries, while VAT rates rose slightly (Lora 2012). Not only have income tax rates declined, but the scope of the system has been altered considerably: it has changed from one which, on average, imposed tax liability at a taxable income level of about 60 percent of per capita GDP in the mid-1980s to one that started at a level 2.3 times per capita GDP a decade later. At the same time, the average level at which the top bracket takes effect has declined sharply from 121 times per capita GDP to only 21 times GDP. With considerable differences from country to country, personal income taxes have become much flatter, with top rates declining to levels comparable to the lower corporate rates. Nonetheless, the share of both income and total taxes collected from the rich (the 
upper quintile) also grew over this period, reflecting the continuing inequality of pre-tax incomes in Latin America and the increasing inequality in the United States and, to a lesser extent, in Canada.

Table 7. Trends in Taxation, 1990-2010

Tax Ratio (T/Y) Of which Income Tax

\begin{tabular}{|c|c|c|c|c|c|c|c|c|c|}
\hline Country & 1990 & 2000 & 2010 & $\begin{array}{l}\text { Percentage } \\
\text { Change } \\
2010 / 1990\end{array}$ & 1990 & 2000 & 2010 & $\begin{array}{l}\text { Percentage } \\
\text { Change } \\
2010 / 1990\end{array}$ & $\begin{array}{l}\text { Ratio of } \\
\text { CIT to PIT } \\
\text { (c.2007) }\end{array}$ \\
\hline Argentina & 16.1 & 21.5 & 33.5 & 108 & 3.7 & 18.5 & 16.2 & 338 & 2.3 \\
\hline Brazil & 28.2 & 30.1 & 32.4 & 15 & 18.1 & 19.3 & 21.2 & 17 & 2.0 \\
\hline Colombia & 9.0 & 14.0 & 17.3 & 92 & 29.9 & 29.3 & 27.9 & -7 & n.a. \\
\hline México & 15.8 & 16.9 & 18.8 & 19 & 27.1 & 27.3 & 27.8 & 2 & 1.1 \\
\hline Peru & 11.8 & 13.9 & 17.4 & 47 & 5.7 & 19.8 & 37.6 & 460 & 4.2 \\
\hline $\begin{array}{l}\text { Unweighted } \\
\text { Average }\end{array}$ & 16.2 & 19.3 & 23.9 & 48 & 16.9 & 22.8 & 26.1 & 54 & 2.4 \\
\hline United States & 27.4 & 29.5 & 24.8 & -10 & 46.8 & 50.5 & 43.6 & -7 & 0.3 \\
\hline Canada & 41.9 & 35.6 & 31.0 & -26 & 48.6 & 50.1 & 46.8 & -4 & 0.3 \\
\hline
\end{tabular}

Sources and Notes: Tax ratios from $\operatorname{OECD}(2012,2012 a)$; excludes local government for Argentina (provincial government included) and for Peru (except for 2010), and does not include fees levied on hydrocarbon production as taxes. "Income tax" includes all taxes classified as such in GFS (personal, corporate, withholding). Ratio of corporate to personal income taxes for Latin America from Cornia, Gomez-Sabaini and Martorano (2012); for North America, calculated from data in OECD (2012).

All these results are sensitive to the particular incidence assumptions employed in the different studies, particularly the incidence of the corporate income tax. As Mahon $(2012,1)$ notes, the available evidence supports the conclusion that "most Latin American fiscal systems have become somewhat more redistributive since 2000." Although most tax reforms in the region have shifted tax structures away from reliance on income taxes and towards consumption taxes, some countries (such as Peru) have sharply increased their reliance on income tax. All countries in the region have increased their tax-to- 
GDP ratios, in contrast to what has happened north of the border. ${ }^{18}$ Before 1970 , most Latin American tax systems collected relatively little tax revenue, and did so in an inefficient and regressive way. Over the next few decades, while income tax rates were cut (in most countries without any offsetting base expansion) the role of the VAT was greatly expanded, with the important effect of strengthening tax administration. As emphasized below, this reform greatly increased the capacity of the state. However, the main responsibility for redistribution remained on the expenditure side and the increases in social spending towards the end of the century (see Table 5) resulted in spending becoming more redistributive in some countries (Barrientos 2011).

A useful summary presentation of the evidence taken from recent work by Mahon (2012) is shown in Table 8, which reports the results of 15 recent studies of fiscal redistribution in the five major Latin American countries examined here. This table illustrates several important points. First, first-order measures of the distributive effect of the fiscal system are invariably very small when measured in terms of changes in the Gini coefficient (which is more sensitive to changes in the middle of the income distribution than at the extremes). Second, such measures also often vary substantially from one year to another (or even for the same year, in the case of Colombia), in part because that they are derived from a variety of different studies, often using differing incidence assumptions, particularly with respect to the incidence of the corporate income tax. Third, as emphasized earlier, social spending programs are generally more effective than taxes in achieving redistribution. Fourth, in three countries total fiscal distribution increased over this short period, while in Colombia and Peru, it appears to have decreased slightly. Finally, although there are exceptions, consumption taxes generally appear to be either slightly regressive or neutral, while income taxes are generally progressive. ${ }^{19}$

\footnotetext{
${ }^{18}$ The exceptionally sharp drop in Canada's tax ratio from its 1990 all-time high reflects the strong fiscal retrenchment required during the 1990s to reduce the high budget deficit and the much more restrained spending of subsequent years. For a more detailed comparison of recent trends in Canada and the United States, see Bird and Zolt (forthcoming).

${ }^{19}$ This conclusion is even more tenuous than the others because in addition to the general problems of different sources, different methods, and different time periods, the scope of the 'consumption' and 'income' taxes being compared varies from country to country and year to year.
} 
Table 8

Recent Studies of Fiscal Redistribution in Latin America

\begin{tabular}{|l|l|l|l|l|l|l|}
\hline Country & Year & RS Index & RS Index & $\begin{array}{l}\text { Combined } \\
\text { RS Index }\end{array}$ & RS Index & RS Index \\
& & Spending & Taxation & & $\begin{array}{l}\text { Consumption } \\
\text { Taxes }\end{array}$ & Income \\
Taxes
\end{tabular}

Source: Mahon (2012). The RS (Reynolds-Smolensky) index is the difference between the Gini coefficients pre- and post-spending or taxation as the case may be. By convention, a positive value indicates a progressive effect (that is, Gini declines) and a negative value a regressive effect.

Despite the marked increase in the importance of income taxes in most major countries in Latin America in recent years, there likely has not been a significant change in the redistributive effect of the tax system. One reason is that relatively little income tax revenue in Latin America comes from the personal 
income taxes, the only important progressive element of the tax system in most countries. In most Latin American countries, income tax revenues are derived primarily from corporate income taxes, the incidence of which may fall on low-income workers and consumers rather than high-income profit recipients (Harberger 2006). However, it may also be argued that corporate income taxes in developing countries are sometimes relatively progressive. For example, Shah and Whalley (1991) contend that the importance of market fragmentation and government regulations in most developing countries suggests that a considerable share of corporate profits arises from economic rents which, if not collected in taxes, will accrue to (presumably wealthy) corporate owners. Clausing $(2012,2013)$ recently underlined this point, emphasizing the extent to which multinational investments similarly reap such rents, especially in countries, like many in Latin America, where there are substantial profits from extracting natural resources. ${ }^{20}$ The conventional view of the corporate income tax as being likely to be shifted to either labor or consumers seems especially questionable in countries like those in Latin America that are becoming more open but at the same time have significant foreign ownership and a rent-generating political and economic structure. If owners, and not workers or consumers, pay all or most of the corporate income tax, then most of the existing tax incidence studies in Latin America (such as those summarized in Table 8) may understate the progressivity of the tax system. ${ }^{21}$

\section{The Fiscal Contract}

Traditional public finance analysis assumes that the state is an autonomous entity that can decide what to do and then do it. ${ }^{22}$ One approach, epitomized by the optimal tax literature (Boadway 2012), treats states as though they were (or should be) benevolent social welfare maximizers. On the other hand, the

${ }^{20}$ Gravelle (2013) generally supports Clausing's argument that much of the corporate tax is borne by owners; however, two other papers in the same journal argue that varying proportions of the tax may be borne by labor.

${ }^{21}$ Some scholars assume that most corporate taxes in Latin America are passed on to consumers in the form of increased prices (Aronson and Bergman 2012). However, no good studies exist on the incidence of the corporate income tax in any Latin American country. Barreix, Roca and Villela (2008), recognizing the uncertainty of the incidence of the corporate income tax simply leave it out of their analysis as do Breceda, Rigolini and Saavedra (2009), an earlier version of which is the source of the estimates in Goni, Lopez and Serven (2008). Although we have not reviewed all the studies relied on by Lustig et al. (2011) and Mahon (2012), the importance of corporate tax revenues in Latin American tax structures (Jimenez, Gomez-Sabaini, and Podesta 2006) and the uncertainty of the incidence of the corporate income tax suggest that conclusions about the distributional effect of increasing 'income taxes' in Latin American countries are at best tentative.

${ }^{22} \mathrm{An}$ important variant of this approach is to assume that the state is not an actor in itself but simply the instrument of specific groups: social classes (Marxism), organized interest groups (Olson 1965), or partisan political parties (Hibbs 1977). These groups act in a self-interested way to increase their command over resources. In all these cases, however, it is usually simply assumed that those who control the state can use its power as they wish. 
public choice approach considers those who control states to be self-interested actors (Brennan and Buchanan 1980). In essence, both approaches assume that "people pay taxes because they must; there is no relationship between the source of state revenue and state output; and spending is a function of rulers' whims (Timmons, 2005, 534)."23

Such views stand in contrast to what Timmons (2005) calls the 'fiscal contract paradigm,' which assumes that governments are viewed as selling citizens services for revenue and hence, like good businessmen, are most likely to respond primarily to the wishes of those who pay. Because taxes are costly and difficult to collect, those who run states will want to reduce such costs by reducing the willingness and ability of citizens to evade or avoid taxes. There are two ways to do so. One approach is to be nice: to make citizens more willing to pay for what the state does by ensuring that what is done is acceptable and seen as beneficial by a majority of those who pay. The other approach is to be tough: to strengthen fiscal administration and make them more afraid of what will happen to them if they do not pay their taxes. ${ }^{24}$ The central fiscal problem of the state from this perspective is to balance its use of these two levers in order to obtain the revenues desired at the least cost. All countries are thus continually seeking a sustainable equilibrium between force and persuasion when it comes to tax compliance. Even if citizens have no realistic exit options and their opportunities to influence state policy through voice are severely limited, states will still want to cultivate loyalty to reduce the costs of tax collection. Similarly, even the most open and liberal democracies need to have credible revenue enforcement mechanisms to prevent high levels of tax evasion.

The fiscal contract approach does not fit easily into what might be called the 'welfarist' view, which takes redistribution as a major goal of the fiscal system and invariably concludes that taxes should be paid mainly by the rich and expenditures targeted mainly to benefit the poor. ${ }^{25}$ In contrast, the fiscal contract view implies both that those who are expected to pay most of the taxes are likely to receive most of the benefits, and that their willingness to pay is tied to the expectation of receiving benefits. These benefits may be indirect in the sense of providing funds to the poor on the condition that they act

\footnotetext{
${ }^{23}$ Of course, this statement is too sweeping because there is a vast literature on tax evasion and compliance and on the effects of taxation on output. Nonetheless, it captures the flavor of much of the tax policy literature.

${ }^{24}$ Although Alesina and Reich (2013) do not discuss the fiscal aspect of 'nation-building,' the positive and punitive approaches mentioned in the text are broadly aligned with the 'benevolent' and 'odious' methods of 'building' a country that are the subject of their paper.

${ }^{25}$ Aronson and Bergman (2012) offer an interesting example of the implicit acceptance of the welfarist approach where they note that one contributor to the conference summarized in their paper noted that part of the failure of Mexico to introduce major tax reforms may be blamed on what he calls the "ideological principle" of the benefit approach. Note 29 (and the accompanying text) offer several possible alternative explanations.
} 
in ways taxpayers value: for example, by ensuring that their children become educated. Discussions of taxation and inequality frequently focus on only two groups: the 'rich' (say, the top quintile, or even the top 1 percent) and the 'poor' (say, the bottom two quintiles). However, in the real world of the Americas, the most critical element may well be how the 'middle' or 'upper middle' (say, the bulk of the population between the 'poor' and the top 1-2 percent of the income distribution) perceive themselves to be treated. ${ }^{26}$

A reasonable assumption is that the poor want some package of basic public services (in addition to jobs), while the rich seek mainly to keep what they have: that is, protection for their property rights. The motto of the Toronto police service is "To Serve and Protect." What the poor want is mainly service, while what the rich want is mainly protection. To the extent that the middle class wants both service and protection, its recent rise to prominence in Latin America may provide an opportunity to change the fiscal contract. In countries in which both growth and democracy have recently flourished, the political equilibrium may change in ways that alter the nature of the implicit fiscal contract underlying political stability and state legitimacy. The newly better-off, the expanding middle class discussed by Ferreira et al. (2013), cannot easily emulate either the rich, who to a large extent not only pay as little as possible in taxes but also make little use of public services, or the poor, who neither pay much nor benefit much. The middle class, and especially the vulnerable middle class, need a stronger public sector to secure their position as much as the poor need it to improve their position. At the same time, the middle class have fewer opportunities than the rich to opt out of the tax system by hiding in the informal sector or by shifting activities offshore. For the first time in Latin America, a significant proportion of the population are now both politically relevant citizens and taxpayers, although they are not often fully aware of how much they pay and hence less concerned than they should be about how their funds are spent. As more people become aware (e.g. through the expansion of the personal income tax and property tax) of the taxes they pay and of the extent to which their wellbeing and the future of their children depend on good state services, the political balance underlying the fiscal contract is likely to change.

\footnotetext{
${ }^{26}$ Others have emphasized various aspects of the fiscal contract approach when discussing recent and possible future developments in Latin America, For related, but distinct, views see, for instance, Mahon (2011, 2012), Cornia, Gomez-Sabaini and Martorano (2012) and ECLAC (2013).
} 


\section{Taxation in the fiscal contract}

One side of a fiscal contract is the tax system. Most political scientists take progressive income taxes to be a good proxy for taxes on the rich and regressive consumption taxes to be an equally good proxy for taxes on the poor (Kato 2003). Although this approximation is at best rough, it is true that most income taxes are paid by those in the top part of the income distribution. On the other hand, much depends on the structure of the personal income tax. Such taxes may, for example, impact most heavily (in relative terms) those who have just entered the tax from the bottom (the lower middle class who may for the first time have moderate levels of income and some property to protect). If so, perceptibly higher tax burdens faced by an expanding middle class may reinforce the normal anti-income tax sentiment of the rich, a phenomenon that has perhaps become more important as income tax rate structures have become flatter. As Table 9 shows, the threshold income level at which Latin Americans begin to pay personal income tax is generally much higher than in developed countries. ${ }^{27}$ In Mexico, for example, the personal income tax does not apply to workers with below-average wages, while in the United States and Canada the threshold level is set much lower, at around 30 percent of the average wage (OECD 2012b). Similarly, the highest rates of the income tax also cut in at much higher levels in many Latin American countries.

\section{Table 9. Personal Income Taxes: Thresholds and Income at Maximum Rate}

(as multiple of average per capita income in 2010).

\begin{tabular}{|c|c|c|}
\hline Country & Threshold & Maximum \\
\hline Argentina & 0.30 & 3.66 \\
\hline Brazil & 1.10 & 2.74 \\
\hline Colombia & 2.83 & 10.65 \\
\hline Mexico & 0.49 & 3.39 \\
\hline Peru & 1.69 & 14.69 \\
\hline Average Latin America & 1.41 & 9.06 \\
\hline Average OECD & 0.24 & 2.38 \\
\hline
\end{tabular}

Source and notes: Lora (2012); 'threshold' is the minimum income level at which personal income tax has to be paid and 'maximum' is the income level at which the highest tax rate is applied.

\footnotetext{
${ }^{27}$ For an interesting further discussion, see ECLAC (2013).
} 
So long as the absolute level of income of the emerging middle class is increasing, the proportion of citizens paying income taxes is likely to grow. In Brazil, for example, a combination of increases in income, formalization of employment, and strengthened tax administration resulted in over 50 percent of those declaring income in 2011 paying income tax, compared to only 36 percent a decade earlier. ${ }^{28}$ Many of those now caught in the tax net would seem to be natural allies of the poor in the sense that both groups tend to want expansion of public sector services like health, education, pensions, and basic public infrastructure services like transit, water, and sewerage.

As Martinez-Vazquez (2008) notes, one of the most striking features of the various major tax changes that took place in Mexico in earlier decades (Gil-Diaz and Thirsk, 1997) was how little effect they had on Mexico's tax ratio (taxes as percent of GDP), which had remained almost constant over the period. He suggested several possible explanations for this constancy. The reforms in tax structure may have been undermined by unrelated ad hoc measures, or they may have been offset by administrative deterioration. Either, or both, of these developments may have occurred less by accident than by design. Alternatively, they may reflect the extent to which Mexican revenues depend on oil prices. ${ }^{29}$ As Table 7 shows, whatever the explanation, although an index of tax reform calculated by Lora (2012) suggests that Mexico and Colombia have carried out more tax reforms than the other Latin American countries discussed here, both still lag behind in effective tax reform. ${ }^{30}$ However, as Table 7 also shows, Peru has altered its tax structure substantially in recent years and Colombia, although not changing tax structure significantly, has significantly increased its total tax revenues. Because countries tend to achieve an equilibrium with respect to the size and nature of their fiscal systems that largely reflects the prevailing balance of political forces, such significant changes in a relatively short period again suggest that there may have been a noticeable change in the politics underlying the national fiscal contract in at least some countries in the region.

Although total taxes and income taxes in particular are not all that high in most of Latin America and the tax systems are not progressive, ${ }^{31}$ the extreme inequality of the region means that the rich nonetheless pay a relatively large share of taxes, so that simply increasing the net fiscal pressure on them may place

${ }_{28}^{28} \mathrm{http} / /$ www.pulsamerica.co.uk/2013/02/25/brazil-over-12-million-currently-pay-income-tax/

${ }^{29}$ Although this point is not discussed further here, ECLAC (2013) properly emphasizes the role played by natural resource revenues in affecting both tax levels and tax structures in Latin America.

${ }^{30}$ The index of tax reform is the simple average of four figures: the average income tax rate (calculated as the average of the maximum personal income tax rate and the corporate rate), income tax productivity (calculated as the ratio of income tax revenues to GDP divided by the average income tax rate), the standard VAT rate, and VAT productivity (c-efficiency), which is similarly defined as the ratio of VAT revenues to GDP divided by the VAT rate.

${ }^{31}$ See Table 8, as well as further discussion in ECLAC (2013) and Wang and Caminada (2011). 
additional strain on the fiscal contract. Tax reform in Latin America does not require governments to give more fiscal benefits to the rich, and it may, quite appropriately, be accompanied by steps to remove some tax expenditures and unwarranted gains on the spending side (such as virtually free tertiary education), as well as by fixing severe legislative malapportionment that makes it all too easy for elites to block tax changes in many countries of the region (Ardanaz and Scartascini 2011). Achieving significant tax reform as conventionally understood may nonetheless require some assurance to those who are going to have to pay more that, in return, their property rights and positions will be more secure than they would be if the present inequalities were simply perpetuated. As Sanchez $(2011,36)$ said with respect to the Chilean reform of the 1990s, for example, “...entrepreneurs agreed to pay more taxes because the new government went to great lengths (in rhetoric and actions) to reassure them that it would maintain a vocation for free markets and an open economy." The new Concertación government was able to negotiate both a combined tax reform and social policy reform, which brought about political peace and the beginning of a move towards a new and perhaps lasting political equilibrium (Boylan 1996).

Even Colombia, often seen as a distributive laggard in the region (Moller 2012), may also be moving down this path. As Flores-Machias (2012) points out, Colombia has imposed a tax on wealth since 2002, which currently applies at rates of 2.4 percent of total liquid assets over USD 1.3 million and 4.8 percent on assets over USD 2.5 million. Revenues from this tax are far from negligible, fluctuating between 2.5 and 5 percent of government revenue and at times amounting to as much as 1 percent of GDP. How was Colombia able to do this? Essentially, by making a 'soft' but credible fiscal contract with the rich to earmark all the proceeds of this tax to security (where it financed an increase in expenditures of about 25 percent) with the explicit objective of expanding the control of the national government over the entire country and improving the security of both persons and business investments - all objectives towards which considerable and perceptible progress was made. Some years ago, Bird (1992) suggested that countries in crisis can adopt reforms long considered impossible. Fairfield (2010), with reference to the Chilean case, suggested that elite solidarity was easier to mobilize behind such reforms when a rightof-center administration is in power, because commitments to spend will be more credible. The Colombia of the first decade of this century satisfied both of these conditions. On the other hand, to achieve acceptance of the wealth tax, the government deliberately backed away from attempting more fundamental tax reforms that business interests opposed. ${ }^{32}$ Moreover, it is as yet unclear whether

\footnotetext{
${ }^{32}$ For example, see the reforms proposed by Bird, Poterba and Slemrod (2005) as well as Moller (2012).
} 
Colombia will follow countries like Brazil, Mexico and Chile in combining a slightly more redistributive tax policy with a more effectively redistributive policy of social spending.

Roberts (2012) stresses the traditional argument that the shift to more 'leftist' governments is a principal reason for the observed change in distributive policy in recent years. He notes, however, both that there has been no apparent shift in ideological views and that even non-left governments moved the same way. Colombia provides a nice illustration of the point emphasized by Hart (2010), that what he calls the 'pro-market Right' can extract more tax revenue more efficiently, with less damage to both equity and growth, than the 'interventionist Left.' This is because the VAT is a more effective and efficient way to tax than the income tax, a point well accepted by social democratic governments in Europe (Lindert 2004) as well as by pro-market governments in Latin America. Perhaps optimistically, Colombia may also illustrate the argument made (in a quite different context) by Bodea and LeBas (2013) that when the provision of public goods through 'clubs' becomes less effective in conflict-prone communities, support for a social contract may increase. Morgan and Kelly (2010)'s findings that Latin Americans tend to be more concerned about inequality when worried about crime also support the view that fighting inequality and instability in personal and community life may go together.

\section{Sustainability in the face of change}

One definition of a sustainable tax system is one that is sufficiently aligned with prevailing economic and political factors to persist without the need for repeated major reforms. Achieving a sustainable tax system in this sense requires striking the right balance between the equity and efficiency aspects of taxation in terms of the equilibrium of political forces. Any state that wishes both to grow and to implement redistributive fiscal policies (regardless of how much redistribution is desired) must first establish an administrable and efficient tax system. For such a system to be politically sustainable in any but a totalitarian setting, it must also be considered to be acceptably fair by a majority of the politically relevant population. One reason why many countries in Latin America for many years had tax systems that were neither efficient nor fair was likely because the politically relevant domain of the fiscal system was considerably smaller than the population as a whole. Profeta and Scabrosetti (2008) argued that the increasing democracy in Latin America in the 1990s had little effect on taxation because of the combination of the extent to which democratic institutions were either captured by the elite or undermined by short-sighted populism with the extreme weakness of state institutional capacity, particularly with respect to fiscal matters. However, the recent marked growth of the middle class in many countries in the region has increased mobility across income classes, and has brought more 
people in direct contact with the tax system. In many countries, this will raise the political salience of fiscal issues and increase the importance of having a system that is perceived to be both acceptably fair and acceptably growth-oriented (Daude and Melguizo 2010). At the same time, as discussed below, tax institutional capacity has been substantially strengthened in most countries. In contrast, over the same period, the increasing concentration of wealth and income at the highest levels in the United States and the removal of a large percentage of the population from the income tax rolls (Burman and Slemrod 2013) has arguably, by reducing the direct contact of many Americans with the tax system, increased the influence of the wealthy over the structure and level of taxation.

More democratic and sustainable outcomes cannot be induced simply by improving fiscal institutions, because a more encompassing and legitimate state is itself the key ingredient needed for a more balanced and sustainable tax system (Brautigam, Fjeldstad, and Moore 2007). Countries with similar economic characteristics in similar economic situations can and do sustain very different tax levels and structures, reflecting both their different political situations and the capacity of the state to deliver services and collect taxes. While economic structures and circumstances clearly influence tax levels and structures, in the end politics almost invariably rule when it comes to shaping the final outcome. The fiscal reality found in most countries reflects less evidence-based decision-making or empirical realities than a changing mixture of ideas, interests, and institutions. Viewed as a whole, tax systems seldom seem to have been designed with any particular objective in mind. ${ }^{33}$ Like other political constructs, tax and spending policies reflect the nature of the social contract that underlies any sustainable society as influenced by such manifestations of both the changing local environment (e.g. democracy in its various forms) and the changing external context (e.g. globalization in its various aspects). ${ }^{34}$

Within this framework, the best tax system is the one that produces the desired amount of revenue in the least costly and distorting way. Countries no longer have the luxury of operating their tax systems in isolation. Although the capacity of most Latin American countries to design and implement effective tax systems has increased substantially over time (as discussed later), the limits on state capacity stressed by Cardenas (2010) remain important and are being increasingly tested in the fiscal field. While 'globalization' has become an overused term, nations have clearly lost some degree of fiscal autonomy

\footnotetext{
${ }^{33}$ History seldom supports the case for an 'intelligent designer' of the tax system. See, for example, the story told in Bank (2010) of how a long series of erratic changes over time led to the evolution of the current U.S. corporate income tax regime.

${ }^{34}$ To some extent, policies may also reflect the long persistence of national and regional social and cultural norms, as emphasized by Inglehart and Welzel (2010) and, in a different way, by Acemoglu and Robinson (2011) .
} 
in recent years, not least with respect to tax policy owing to increased competition for portfolio investment, qualified labor, financial services, business headquarters, and, most importantly for developing countries, foreign direct investment.

The traditional tax regime for taxing cross-border transactions rests on a stylized set of facts: small flows of cross border investments; relatively small numbers of companies engaged in international operations; heavy reliance on fixed assets for production; relatively small amounts of cross-border portfolio investments by individuals; and minor concerns with international mobility of tax bases and international tax evasions (McLure 2001). However, familiar tax labels are increasingly losing their meaning as lawyers and investment bankers convert, with relative ease, equity to debt, business profits to royalties, leases to sales, and ordinary income to capital gains, or the other way around. Combined with the disaggregation of production resulting in different operations in different countries, these factors have changed the business tax base. The increased share of value-added arising from services and intangibles makes it harder to locate the source of corporate income and thus harder for countries to tax corporate income. Increased intra-company trade makes it easier to avoid or evade taxes. Increased mobility of capital makes it harder to tax income. It may also be harder to tax higher labor incomes, as labor becomes more mobile, as traditional employer-employee relationships evolve into independent contractor status, and as owner-managers convert labor income into capital income. Even VAT revenues may be challenged as electronic commerce makes it more difficult to enforce tax on some cross-border transactions. The taxman's life is not becoming easier in Latin America, or anywhere else. Nonetheless, despite the increasingly tight international economic constraints on tax policy, it is still undoubtedly the case that no country in Latin America is anywhere near the limits of what it can do, it if wants to, to impose a fairer (or, for that matter, a more efficient) tax system. ${ }^{35}$

\section{A Look Back - and Ahead ${ }^{36}$}

Consider how the western democracies first got into the business of progressive taxation. In the United States, for example, as Weisman $(2002,366)$ shows, over the course of prolonged discussions from 1860

\footnotetext{
${ }^{35}$ Lora $(2012,31)$ suggests that, despite the many tax reforms mentioned earlier, most Latin American countries have used perhaps "only 30 percent of the space of reform" although this assertion is at best tenuous given the narrow definition of the "reform space" considered in his study (see note 26 above).

${ }^{36}$ Portions of this section follow closely some of the material in Bird (2013), although the argument is developed here in more detail with respect to the Americas.
} 
to 1920, "economic crises and wars helped create a consensus for an income tax that falls most heavily on the wealthiest taxpayers." This lengthy debate about taxes was not so much about tax policy but rather about what kind of society Americans wanted. This consensus, a sort of fiscal contract, lasted until about 1970 . Since then ideas about the relevant balance between taxes and society have again been in flux in the United States. In particular, progressive taxation appears to have lost much of its political appeal (Blyth 2000).

\section{Balancing equity and efficiency}

Other countries have reached different compromises. Alesina and Angeletos (2005) suggest, for example, that two models of redistributive taxation exist in developed countries. At one position is the United States, with relatively low taxes and low redistribution, while at the other are countries such as Sweden, with high taxes and high redistribution. They attribute the difference to, essentially, selffulfilling expectations. In the United States, or so they argue, the general belief is that effort is causally related to income, so that those who make the effort, and consequently receive the income, are entitled to retain a large share of the fruits of their efforts. In the terms used by Musgrave and Musgrave (1989), the "entitlement" view is strongly entrenched in the United States. The relatively unequal distribution of income is considered fair because it is believed to reflect differential effort to a considerable degree. Because tax rates are low, so are tax distortions, with the result that high effort may indeed yield high after-tax income.

In contrast, Alesina and Angeletos (2005) suggest that in many European countries, the pervasive belief appears to be that high income reflects not so much high effort as good connections or even corruption. Because high taxes resulting from this belief system substantially reduce after-tax income, the connection between high effort and high income is indeed greatly weakened. This belief, they suggest, is strongly grounded in the prevalent social reality. Interestingly, however, perhaps reflecting the surprisingly good economic results discussed earlier, it appears that Mexicans and Brazilians are almost as convinced as Americans that hard work is the most important factor in achieving financial success. ${ }^{37}$

In any case, most high-tax countries have, in practice, substantially blunted the disincentive effect of taxation by lowering tax rates and favoring investment activities (Lindert 2004). Two distinct fiscal

${ }^{37}$ http://www.pewglobal.org/question-search/?qid=1458\&cntIDs=@2-@6-@6.50-@8-@32-@38-@50\&stdIDs=@201201 
equilibria are visible in modern democratic societies: big government, with redistributive expenditures but not very progressive taxes (Sweden), and small government, with more progressive taxes but less redistributive expenditures (the United States). The implications of choosing a larger and more redistributive public sector for tax policy are not necessarily what one might expect. Although the larger the government share of economic activity the more damaging bad tax policy choices can be, voters in such countries generally support more pro-growth (and less progressive) tax structures with lower effective tax rates on capital income, lower property taxes, and relatively higher taxes on labor income and consumption (especially on socially damaging activities such as smoking, drinking, and environmental damage). On the other hand, countries like the United States with smaller government sectors tend to have higher taxes on capital and wages and lower taxes on consumption, thus placing relatively more of the tax burden on more elastic factor supplies, with consequently more damaging effects on resource allocation and growth. It is thus not surprising to find, as Steinmo (1993) emphasized some years ago, that the income tax in the United States is much more progressive than that in Sweden, and that indeed it remains one of the most progressive in the world (OECD 2008).

Additional evidence that democratic polities do learn from experience, and do, over time, tend to reward parties that follow more prudent economic policies is provided by studies of subnational debt policy in the United States (Inman 2003) and Canada (Bird and Tassonyi 2003). Blyth $(2002,274)$ puts the same point another way when he notes that "political economies ...are ...evolutionary systems populated by agents who learn and apply those lessons in daily practice." The critical argument in Lindert (2004) is that in a well-functioning state, adequate feedback mechanisms are in place to warn when sustainable limits are being breached. Such mechanisms may take the form of the "exit" mechanisms commonly emphasized by economists (as when over-taxed resources flee a jurisdiction) or the "voice" mechanisms stressed by political scientists (as when governments are changed to carry out more prudent policies) or, as is most common, both may exist. But the key point is that to avoid disaster, such 'error-correcting mechanisms' must exist in sustainable states.

No government is always competent; none is omniscient; not all are always well-intentioned. Mistakes will be made. The key sustainability problem that all societies face is how to minimize the severity of such mistakes. As Lindert (2004) demonstrates, this is done by muting the anti-growth aspects of proredistribution spending policy by a more pro-growth tax policy. Redistributional policies that in themselves might have been unsustainable in the long run because they would impose excessive distortionary costs on resource allocation are made sustainable in part by direct measures to reform the 
tax system to reduce such costs. In the story told by Bird and Tassonyi (2003) about subnational debt, much the same end is achieved by subjecting governments to constant pressures from both exit (market forces) and voice (elections). Macroeconomic policies (subnational borrowing) that in themselves might have led to an unsustainable situation in the long run thus become sustainable over time by an evolution in both institutions (capital markets) and ideas (political rewards for conservative fiscal measures).

The search for a sustainable fiscal contract is a continuous process in every country. In many Latin American countries for a long time, it appeared that no viable democratic social consensus with the right balance between equity and efficiency in taxation was attainable. Many countries in the region were (and some still are) far from being perfect democracies (Snyder and Samuels 2001). They were instead what may be called "democratically exploitative" states -- states in which those in power use the levers of power in large part for self-aggrandizement or in support of their particular group or interests. Over the last couple of decades, the rise of the middle class has contributed to democratization in many Latin American countries. (Ferreira et al. 2013). This does not mean, however, that each country in this heterogeneous region will reach similar fiscal contracts. What is right, or at least feasible, in Chile or Brazil, for example, may not be desirable or possible in Colombia or Honduras.

\section{Making tax systems work}

Taxation is, always and everywhere, what has been called a "contested concept" (Sabates and Schneider 2003). Some pay; some don't pay. Some pay more than others. Some receive compensating services; some do not. Such matters are, in democratic states, resolved through political channels. Indeed, history suggests that the need to secure an adequate degree of consensus from the taxed is one of the principal ways in which, over the centuries, democratic institutions have spread. No non-dictatorial government in this age of information and mobility can long stay in power without securing a certain degree of consent from the populace, not least in the area of taxation. State legitimacy thus rests to a considerable extent on citizens' "quasi-voluntary compliance" (Levi 1988) with respect to taxation. To secure such compliance, tax systems must, over time, represent in some sense the basic values of at least a minimum supporting coalition of the population. As empirical evidence shows, tax compliance depends to a marked extent on the level of tax morale in the population, and that in turn rests significantly on how favorably people perceive how they are governed (Torgler, Schaffner and Mclntyre 2010). 
Taxation is one of the few ways in which the wealthy may be made less wealthy, short of outright confiscation. Although attempts to redistribute income through taxation have not been markedly effective anywhere (Bird and Zolt 2005), as even rich countries have learned in recent years, it may nonetheless be important in political terms to impose highly visible taxes on those who gain the most because sustainable tax policy needs to be accepted as fair by those affected. Two interesting features of inequality in Latin America, from a fiscal perspective, are the extent to which inequality arises from a very high degree of concentration at the very top of the income distribution and inequality's relation to the extremely unequal distribution of land. The second point has long been recognized, as shown by the long, and not too successful, history of attempts at direct land reform in the region (Dorner 1992). The fiscal path to inducing land reform has had no more success in Latin America than anywhere else (Bird 1974). Property tax revenues are low in most Latin American countries. The coverage of the tax is not comprehensive, assessments are low, and collection rates are often low as well. Although nominal rates are also low, governments usually find rate increases in this very visible tax difficult to sell politically. Engerman and Sokoloff (2001) argue that one reason for the relatively persistent inequality in Latin America compared to North America is the much weaker role of local government (largely dependent on property taxes) in Latin America, reflecting the underlying political capture of the central government by the dominant elites. The recent interest in decentralization in many Latin American countries may be seen as both a response to the increasing democratization of the polity and a response to the increasing need for governments to be seen as responsive to local needs in an equitable fashion (Brosio and Jimenez 2012). One result may be renewed attention to local property taxation as a desirable and fair means of taxation, although as yet there is little evidence of this (ECLAC 2013).

At one level, the high concentration of income and wealth at the top in Latin America may appear to make the task of fiscal redistribution easier because a progressive income tax, or a wealth tax, would apply to a relatively small number of people. Indeed, as Tanzi (1966) noted many years ago, many common arguments as to why personal income taxes are difficult to implement in developing countries fail when it comes to taxing the rich in Latin America. There are not many of them, they certainly have the capacity to comply with the tax regime, and so on. The real question is political: can the obvious opposition of the wealthy elite to such taxes be overcome? The wealthy can block such efforts in many ways: they can block progressive legislation from being passed (Ardanaz and Scartascini 2011); they can introduce incentives and provisions to blunt its effects (doing so in the name of the "national interest"); they can corrupt the administrative process; they can use their resources to mute and delay it in many 
legal ways; or they and their resources can leave the jurisdiction. All this and more goes on in most Latin American countries, and has done so for many years (Gomez Sabaini and Jimenez 2012). ${ }^{38}$

The opening of capital markets, combined with weak international tax enforcement capabilities, makes it harder to tax the wealthy on much of their income from capital. The political reality in most countries means that it is not easy to do so. In the end, within limits, countries get the tax systems that those who run them want, and those who run many Latin American countries have not favored a very redistributive tax system. However, the increasing importance of the middle class and the interest of both the rich and the middle class in securing what they have, even if one price for doing so is to pay more taxes in part to help redistribution efforts, may have begun to alter the political balance and the nature of the fiscal contract in some countries.

Although the central social and economic problem in many Latin American countries remains inequality, the lack of government accountability also persists. A good tax system is critical to solving both problems. As noted earlier, an important factor shaping the nature of the fiscal contract is the cost of tax collection. Gordon and Li (2009) and Kenney and Winer (2006) emphasize, in somewhat different ways, that when economic and technological changes alter the relative costs of imposing different taxes, both tax structures and tax levels adjust. In recent years the widespread adoption of the VAT has played a central role in improving the effectiveness of tax administration in Latin America, because the successful implementation of this tax usually requires a substantial upgrading of the capacity to administer taxes (Mahon 2011). A recent study of the Brazilian state VAT demonstrates (Pinhanez 2008) that one important result of introducing the VAT was that it strengthened both accountability within the public sector and the degree of trust between taxpayers and tax officials. ${ }^{39}$ Provided the political will exists to increase tax revenues, the improvement made to administrative capacities of many countries by adopting a VAT makes it more feasible to reform other parts of the tax system than in previous years.

\footnotetext{
${ }^{38}$ Similar pressures have been at work in developed countries also in recent years. Krugman (2002) provides a nice review of the efforts to eliminate the estate tax in the U.S., a story told in much more detail in Graetz and Shapiro (2006) and one that is similar the earlier Canadian experience (Bird 1978).

${ }^{39}$ As one businessman interviewed by Pinhanez (2008) said: "It is not that we are really collaborating with each other. But we are talking now." A tax official's take was a bit more cynical: "It is not that we are helping out or consulting for the private sector. We are showing them that we know their business. They have to abide by the law. We have the data on them and that's it." Nonetheless, one of the most striking outcomes of the reform has been the generally more open relations between state tax administrations and taxpayers groups. They are not friends; but they talk to each other within a similar framework of understanding of how different sectors work.
} 
As studies from Taylor (1965) to Moller (2012) have shown for Colombia it is not hard to think of ways to tax the rich more effectively, through indirect means such as taxes on vehicles as well as through such direct means as taxes on income and wealth (land, estates). Indeed, to the extent that some of the income of the rich reflects "rents" secured through political connections or monopolies, such taxation may carry with it few distortionary costs. On the other hand, attempts to impose unduly redistributive taxes may backfire so that countries end up with smaller and less redistributive public sectors (IDB 1998), and even the most redistributive taxes are unlikely to have much effect on income redistribution (Harberger 2006). From the perspective of redressing income inequality and poverty, it remains clear that the most important function of the tax system is to provide funding for pro-poor (or at least not 'pro-rich') spending programs.

The dominant policy ideas in different countries (such as equity, efficiency, and growth), like the dominant economic and social interests (such as capital, labor, regional, ethnic group, rich, and poor) and the key political institutions (democracy, decentralization, budgetary), and economic institutions (free trade, protectionism, macroeconomic policy, and market structure) all interact in the formulation and implementation of tax policy. This changing interplay over time affects the level of taxation, the structure of taxation, and many of its critical details, such as the progressivity of rates. Indeed, taxation is one of the major battlegrounds on which we can observe the working out of these complex forces.

Viewed from this perspective, only recently have some Latin American countries begun to experience the cycle that produced the (more or less) redistributive fiscal state now found in most developed countries. During this long preparatory period, the idea of the desirability, and perhaps necessity, of a more effectively progressive fiscal system becomes sufficiently established such that when the time is ripe, progressive taxes are in fact adopted. Governments in many Latin American countries have struggled both economically and politically. Even those governments with a certain degree of political legitimacy and stability have faced substantial constraints on fiscal policy. Until countries achieve an adequate degree of political consensus on what should be done, no significant tax changes are likely to be made. As Lledo, Schneider, and Moore $(2003,47)$ noted, the problem in Latin America for many years has been that most countries lack “...an (implicit) social contract between governments and the general populace of the kind that is embedded in taxation and fiscal principles and practices in politically more stable parts of the world." Over the last decade, however, some signs of change have begun to emerge, as economic growth has led both to greater economic mobility and more robust democratic governments resulting from a larger and more empowered middle class (Ferreira et al. 2013). On the 
other hand, some observers in the United States have recently expressed considerable concern about the apparent fracturing of the social contract in that country in recent decades (Roemer 2011), as reflected not least in the bitter and unresolved battles taking place over both the size and structure of taxation and expenditure (Bargain et al, 2013).

\section{Lessons to be learned}

What lessons may developing countries draw from the divergent experiences of Latin America and the United States, particularly with respect to the design, redistributive effect, and effectiveness of tax policy and with respect to the appropriate role of the state and its fiscal system in achieving an environment that is both conducive to economic growth and to the development of a stable and sustainable political system ? $^{40}$

Had Latin American countries adopted the common 1960s prescription for much heavier reliance on income taxes in designing their tax regimes (Bird 2012), would they be better or worse off than they are now? If the United States had followed the rest of the world and adopted a national VAT some years ago, would it be better or worse off? A strong argument can be made that Latin America is better off for having ignored the conventional wisdom and adopted the VAT route to developing somewhat larger states, not least because the stronger tax administrations that resulted from following this less conflictstrewn path may now enable them to strengthen their income taxes. And it may be that the United States would have been better off by joining Canada, Japan, and Australia in adopting a VAT years ago. Even if the United States seeks to maintain its current size of government, the United States could both improve its competitive position and reduce its continuing political struggle by ceasing to rely so heavily on the personal and corporate income tax to solve most of its fiscal problems.

Brededa, Rigolini and Saavedra (2009) note that the structure of both social spending and taxation in Latin America are closer to that in the United States than in Europe. They suggest that the underlying fiscal contracts in the United States and Latin America appear to be converging because both derive most of their tax revenues from the wealthy, who get little in return from the state. This results in a minimalist welfare state, in contrast to the more inclusive (and more redistributive) models found in

\footnotetext{
${ }^{40}$ See Brautigam, Fjeldstad and Moore (2007) on the limited but still potentially significant role of fiscal policy in this respect.
} 
Europe and even, to a lesser extent, in Canada. ${ }^{41}$ This conclusion may be supported to some extent by the evidence cited earlier suggesting that in many important ways, attitudes and basic social norms in Latin America are closer to those in North America than those in northern Europe. Nonetheless, a stronger welfare state may be needed in some countries to maintain socio-economic stability. If so, the overlapping economic and political elites that still dominate in most Latin American countries may soon have to follow the path (familiar from European fiscal history) of choosing between prolonged and even violent political confrontations on redistributive issues, or continuing in the direction of turning formal political democracy into a more socially inclusive process of participatory development of the underlying social (and fiscal) contract. ${ }^{42}$

The poor have little choice but to rely on public services, no matter how scanty or low-quality they may be. The emerging middle class may, in some countries, have the choice of focusing on improving the social security system with respect to health and pensions, but in all countries they have to choose whether to educate their children in the public system or in the generally better private system now utilized largely by the wealthy and upper-middle class. The public sector may finance such access to private education, as to some extent is done in Chile and Colombia, just as it may make the social insurance system more equitable and efficient. But these alternatives, like the straightforward extension of access to (and improvement of the quality of) the public sector, will cost money and require additional tax revenue. The conundrum facing Latin American policy makers is thus whether to focus on expanding and improving traditional public sector services, or instead to focus on providing increased access for more people to the better alternatives now available from private providers. In some instances, the latter approach may be more likely to deliver perceptible benefits to more individuals, presumably increasing their willingness to support the increased taxes needed to finance expanded public sector social spending. In addition, many Latin American countries have decentralized public sector provisions primarily to better match public services with the wishes and needs of local communities (Brosio and Jimenez 2012). The welfare state that might result is more likely to resemble

\footnotetext{
${ }^{41}$ Interestingly, Breceda, Rigolini and Saavedra $(2009,722)$ exclude pensions from their analysis on the ground that it is "difficult to assess their redistributive nature" owing to their intertemporal dimension and the mix of financing. This is a bit odd, because it is not that hard to disentangle the financing side as Bird and Smart (2013) do for Latin America. However, this omission makes little difference to their argument since public pensions in Latin America go largely to the middle class although financed in many countries to a significant extent from general revenues.

${ }^{42}$ For interesting discussions of the paths traced by the 'fiscal sociology' of different countries, see, for example, the studies in Martin, Malhotra, and Prasad (2009).
} 
the smaller American model than the much more lavish European one, but it would still be a major improvement for many Latin American countries.

The obvious answer to the fiscal dilemma arising from the combination of increased political pressure for more services and less political support for income taxes is to rely more heavily on consumption taxes. Consumption taxes generally impose a relatively larger burden on lower than on higher income groups, but they are paid much more by the middle class than by the poor. ${ }^{43}$ In the United States, where the distribution of tax expenditures is skewed towards upper and upper-middle income-earners (those who pay the bulk of the income tax), recalibrating the fiscal balance between expenditures and revenues may prove an even more difficult exercise than in many Latin American countries. In Latin America, however, where VAT burdens fall most heavily on the growing (and consuming) middle classes, and where those middle classes are becoming more critical to political success, it is not surprising that considerable attention has been paid in recent years to the major redistributive expenditures on education and health, with lower-income groups also benefiting to some extent. On the other hand, the wealthy in Latin America, as is also increasingly true in the United States, are basically outside the public service delivery system, which does not necessarily augur well for the future sustainability of either fiscal contract unless a greater effort is devoted to creating a consensus in terms of social norms and the acceptance of national political goals (Alesina and Reich 2013).

Countries can maintain or increase state capacity to collect tax revenues only if the fiscal contract is adhered to so that taxpayers believe that the funds will be spent wisely and efficiently - that is, in ways that they perceive as benefiting them either directly (in terms of providing valued public services) or indirectly (in terms of strengthening a sustainable legal and political framework to support property rights). How well the Americas, North and South, will manage this difficult task in the years to come remains to be seen.

\footnotetext{
${ }^{43}$ Although at present consumption taxes in many countries may nonetheless impose a heavy and undesirable burden on the poor, it is not difficult to design and implement fairer taxes. See Bird and Miller (1989) for suggestions on how excise taxes and user charges can be made less burdensome in developing countries and, more recently, the important proposal by Barreix, Bes and Roca (2010) on how the same can be done for a broad-based VAT by creating an offsetting credit for lower income groups administered in the same way as the conditional cash transfers already in place in a number of countries in Latin America, including Brazil, Colombia and Mexico.
} 


\section{References}

Acemoglu, D. and J. Robinson (2012) Why Nations Fail (Crown Publishing Group).

Afonso, J. et al. (2012) "Reflections on Two Decades of Social-Spending Decentralization," in G. Brosio and J. Jimenez, eds. (2013) Decentralization and Reform in Latin America (Edward Elgar), 70-111.

Alesina, A. and G. Angeletos (2005) "Fairness and Redistribution," American Economic Review, 95 (4): 960-980.

Alesina, A. and B. Reich (2013) Nation Building, NBER Working Paper 18839, February.

Angrist, J. et al. (2002) "Vouchers for Private Schooling in Colombia: Evidence from a Randomized Natural Experiment," American Economic Review

Ardanaz, M. and C. Scartascini (2011) Why Don't We Tax the Rich? Inequality, Legislative Malapportionment, and Personal Income Taxation around the World, IDB Working Paper Series No. !DBWP-282, November.

Arnson, C. and M. Bergman (2012) Taxation and Equality in Latin America, Woodrow Wilson Center Update on the Americas, June.

Atkinson, A. (2012) "The Mirrlees Review and the State of Public Economics," Journal of Economic Literature, 50 (3): 770-780.

Atkinson, A. and A. Brandolini (2011) On the Identification of the 'Middle Class,' Society for the Study of Economic Inequality, ECINEQ WP 2011-217, September.

Azevedo, J. et al. (2013) Fifteen Years of Inequality in Latin America: How Have Labor Markets Helped? World Bank Policy Research Paper 6384, March.

Banerjee, A. and E. Duflo (2008) "What is Middle Class about the Middle Classes around the World?" Journal of Economic Perspectives, 22 (2): 3-28.

Bank, S. (2010) From Sword to Shield: The Transformation of the Corporate Income Tax 1861 to Present (Oxford: Oxford University Press).

Bargain, O. et al. (2013) Partisan Tax Policy and Income Inequality in the U.S., 1979-2010, IZA Discussion Paper No. 7190, January.

Barreix, A., M. Bes and J. Roca (2012) Solving the Impossible Trinity of Consumption Taxes: Personalized VAT: Increasing Revenue Collection and Compensating the Poor, Inter-American Development Bank, Washington.

Barreix, A. and J. Roca (2007) "Strengthening a Fiscal Pillar: The Uruguayan Dual Income Tax," CEPAL Review, 92 (August): 121-40. 
Barreix, A., J. Roca, and L. Villela (2007) Fiscal Policy and Equity Estimation of the Progressivity and Redistributive Capacity of Taxes and Social Public Expenditure in the Andean Countries, Inter-American Development Bank ITAL-INT Working Paper 33.

Barrientos, A. (2011) On the Distributional Implications of Social Protection Reforms in Latin America, UNU-WIDER Working Paper No. 2011/69, November.

Bird, R. (1974) Taxing Agricultural Land in Developing Countries (Cambridge, MA.: Harvard University Press).

Bird, R. (1978) “Canada's Vanishing Death Taxes," Osgoode Hall Law Journal, 16 (1): 133-45.

Bird, R. (1992) "Tax Reform in Latin America: A Review of Some Recent Experiences," Latin American Research Review, 27: 7-34.

Bird, R. (2012) Taxation and Development: What have we Learned from Fifty Years of Research? ICTD Working Paper 1, International Centre for Tax and Development, Institute of Development Studies, Brighton UK, April.

Bird, R. (2013) "Foreign Advice and Tax Policy in Developing Countries," this volume.

Bird, R. and B. Miller (1989) "Taxation, Pricing and the Poor," in R. Bird and S. Horton, eds.,Government Policy and the Poor in Developing Countries (Toronto: University of Toronto Press), 49-80.

Bird, R., J. Poterba, and J. Slemrod (2005) Fiscal Reform in Colombia: Problems and Prospects (Cambridge, MA: MIT Press).

Bird, R. and M. Smart (2013) "Financing Social Insurance in Developing Countries: Payroll or Value Added Taxes?" In H. Hinte and D. Robalino, eds., Social Security, Informal Sector and Employment in Middle Income Countries: How to Protect Workers While Creating Good Jobs (London: Oxford University Press), 266-95.

Bird, R. and A. Tassonyi (2003) “Constraining Subnational Fiscal Behavior in Canada : Different Approaches, Similar Results ?" in J. Rodden, G. Eskeland, and J. Litvack, eds., Fiscal Decentralization and the Challenge of Hard Budget Constraints (Cambridge, MA: MIT Press), 85-132.

Bird, R. and E. Zolt (2005) "Redistribution via Taxation: The Limited Role of the Personal Income Tax in Developing Countries," UCLA Law Review, 52 (6): 1627-95.

Bird, R. and E. Zolt (2011) “Dual Income Taxation: A Promising Path to Tax Reform for Developing Countries" World Development, 39 (10): 1691-1703.

Bird, R. and E. Zolt (forthcoming) "Taxes, Spending and Inequality in Canada and the United States: Two Stories or One?" 
Blofeld, M. (2011) The Great Gap: Inequality and the Politics of Redistribution in Latin America (Penn State University Press).

Blyth, M. (2002) Great Transformations: Economic Ideas and Institutional Change in the Twentieth Century (Cambridge: Cambridge University Press).

Boadway, R. (2012) From Optimal Tax Theory to Tax Policy (Cambridge, MA: MIT Press).

Bodea, C. and A. LeBas (2013) The Origins of Social Contracts: Attitudes toward Taxation in Urban Nigeria, Centre for the Study of African Economies, University of Oxford, CSAE Working Paper WPS/2013-02, January.

Boylan, D. (1996) "Taxation and Transition: The Politics of the 1990 Chilean Tax Reform," Latin American Research Review, 31 (1): 7-31.

Brautigam, D., O-H. Feljstad, and M. Moore (2007) Taxation and State-Building in Developing Countries (Cambridge: Cambridge University Press).

Breceda, K., Rigolini, J. and Saavedra, J. (2009) "Latin America and the Social Contract: Patterns of Social Spending and Taxation," Population and Development Review 35(4): 721-48.

Brennan, G. and J. Buchanan (1980) The Power to Tax (New York: Cambridge University Press).

Breton, A. (1996) Competitive Governments (Cambridge: Cambridge University Press).

Brosio, G. and J. Jimenez (2012) Decentralization and Reform in Latin America: Improving Intergovernmental Relations (Edward Elgar).

Brunori, P., F. Ferreira, and V. Peragine (2013) Inequality of Opportunity, Income Inequality and Economic Mobility: Some International Comparisons, ECINEQ WP-2013-284, January.

Burman, L. and J. Slemrod (2013) Taxes in America (Oxford: Oxford University Press).

Canavire-Bacarreza, G., J. Martinez-Vazquez, and V. Vulovic (2012) The Role of Taxation and Public Expenditures in Economic Growth and Income Inequality in Latin America, Paper prepared for InterAmerican Development Bank, May.

Cardenas, M. (2010) 'State Capacity in Latin America," Economia, 10(2): 1-45.

Clark, G. (2013) What is the True Rate of Social Mobility? Evidence from the Information Content of Surnames, University of California Davis, paper presented at American Economic Association conference, January

Clausing, K. (2012) "In Search of Corporate Tax Incidence." Tax Law Review, 65 (3): 433-472.

Clausing, K. (2013) “Who Pays the Corporate Income Tax in a Global Economy?” National Tax Journal, 66 (1): 151-184. 
Corak, M. (2012) "Inequality from Generation to Generation: The United States in Comparison," in R. Rycroft, ed., The Economics of Inequality, Poverty and Discrimination in the $21^{\text {st }}$ Century (ABC-CLIO). http://milescorak.files.wordpress.com/2012/01/inequality-from-generation-to-generation-the-unitedstates-in-comparison-v3.pdf

Cornia, G., J.C. Gomez-Sabaini, and B. Martorano (2012) A New Fiscal Pact, Tax Policy Changes, and Income Inequality: Latin America during the Last Decade, Departamento di Scienze Economiche Universita degli Sudi de Firenze, Working Paper No. 03/2012, February.

Daude, C. and A. Melguizo (2010) Taxation and More Representation? On Fiscal Policy, Social Mobility, and Democracy in Latin America,Working Paper No. 204, OECD Development Centre, September. Davies, J., ed. (2008) Personal Wealth from a Global Perspective (Oxford: Oxford University Press). Davies, J. et al. (2008) "The World Distribution of Household Wealth," in J. Davies, Personal Wealth in the Global Economy (Oxford: Oxford University Press), 395-418.

De Ferranti, D. et al. (2004) Inequality in Latin America: Breaking with History? Washington, DC. The World Bank.

Dorner, P. (1992) Latin American Land Reforms in Theory and Practice: A Retrospective Analysis (Madison: The University of Wisconsin Press).

Duncan, D. and K. Peter (2012) Unequal Inequalities: Do Progressive Taxes Reduce Income Inequality? IZA Working Paper No. 6910, October.

ECLAC (United Nations Economic Commission for Latin America and the Caribbean) (2013) Fiscal Panorama of Latin America and the Caribbean: Tax Reform and the Renewal of the Fiscal Covenant (Santiago, Chile: United Nations).

Engerman, S. and K. Sokoloff (2001) Inequality, Institutions and Differential Patterns of Growth among New World Economies, WP 9052, National Bureau of Economic Research, Cambridge, MA, February. Fairfield, T. (2010) "Business Power and Tax Reform: Taxing Income and Profits in Chile and Argentina" Latin American Politics and Society 52(2): 37-71.

Feldstein, M. (2012) “The Mirrlees Review," Journal of Economic Literature, 50 (3): 781-790.

Ferreira, F. et al. (2013) Economic Mobility and the Rise of the Latin American Middle Class (Washington, DC: The World Bank).

Flores-Machias, E. (2012) Financing Security through Elite Taxation: The Case of Colombia's 'Democratic Security Taxes', Working Paper 3, International Centre for Tax and Development, July. Gasparini, L. and N. Lustig (2011) The Rise and Fall of Income Inequality in Latin America, Tulane Economics Working Paper Series 1110, February. 
Gil-Diaz, F. and W. Thirsk (1997) “Mexico's Protracted Tax Reform,” in W. Thirsk, ed., Tax Reform in Developing Countries (Washington: World Bank).

Goldin, C., and L. Katz (2008) The Race between Education and Technology (Cambridge, MA: Harvard University Press).

Gomez Sabaini, J. and J. Jimenez (2012) Tax Structure and Tax Evasion in Latin America, Macroeonomia del desarrollo serie 118, CEPAL, Santiago, February.

Goni, E., H. Lopez and L. Serven (2011) "Fiscal Redistribution and Income inequality in Latin America," World Development, 39(9): 1558-1569.

Gordon, R. and W. Li (2009) "Tax Structures in Developing Countries: Many Puzzles and a Possible Explanation," Journal of Public Economics, 93(7-8): 855-866.

Graetz, M. and I. Shapiro (2006) Death by a Thousand Cuts: The Fight over Taxing Inherited Wealth (Princeton University Press).

Gravelle, J. (2013) “Corporate Tax Incidence: Review of General Equilibrium Analysis and Estimates," National Tax Journal, 66 (1): 185-214.

Harberger, A. (2006) "Taxation and Income Redistribution: Myths and Realities," in J. Alm, J. MartinezVazquez, and M. Rider, eds., The Challenges of Tax Reform in a Global Economy (Springer).

Harris, E., and F. Sammartino (2011) "Trends in the Distribution of Household Income Between 1979 and 2007," Congressional Budget Office.

Hart, A. "Death of the Partisan? Globablization and Taxation in South America, 1990-2006," Comparative Political Studies, 43(3): 304-328.

Hibbs, D. (1977) "Political Parties and Macroeconomic Policy," American Political Science Review, 71 (4): Hirschman, A. (1970) Exit, Voice and Loyalty (Cambridge, MA: Harvard University Press). Hungerford, T.L. (2008), Income Inequality, Income Mobility, and Economic Policy: U.S. Trends in the 1980s and 1990s, Congressional Research Service.

IDB (Inter-American Development Bank) (1998) Facing Up to Inequality in LatinAmerica. Economic and Social Progress in Latin America 1998-99 (Washington).

Inglehart, R. and c. Welzel (2010) “Changing Mass Priorities: the Link between Modernization and Democracy," Perspectives on Politics, 8(2): 551-567.

Inman, R. (2003) "Transfers and Bailouts: Enforcing Local Fiscal Discipline with Lessons from U.S. Federalism," in J. Rodden, G. Eskeland, and J. Litvack, eds., Fiscal Decentralization and the Challenge of Hard Budget Constraints (Cambridge, MA: MIT Press). 
Jantti, M. et al. (2006) American Exceptionalism in a New Light: A Comparison of Intergenerational Earnings Mobility in the Nordic Countries, the United Kingdom and the United States, IZA (Bonn) DP 1938, January.

Jimenez, J., J. Gomez-Sabaini, and A. Podesta (2010) Tax Gap and Equity in Latin America and the Caribbean. Fiscal Studies No. 16 (Eschborn: GTZ).

Joint Committee on Taxation (2012) Overview of the Federal Tax System as In Effect for 2012, available at http://www.jct.gov/piblications.html?func=startdown\&id=4400. Washington.

Kato, J. (2003) Regressive Taxation and the Welfare State (Cambridge: Cambridge University Press).

Keen, M. (2013) Targeting, Cascading, and Indirect Tax Design, IMF Working Paper, WP/13/57, February. Kenney, L. and S. Winer (2006) "Tax Systems in the World: An Empirical Investigation into the Importance of Tax Bases, Administration Costs, Scale and Political Regime," International Tax and Public Finance, 13: 181-215.

Kleinbard, E.D. (2012) “Paul Ryan's Roadmap to Inequality” (September 6, 2012). 136 Tax Notes (September 6), 1195-

Krebs, T., P. Krishna, and W. Maloney (2013) Income Mobility and Welfare, IMF Working Paper $\mathrm{WP} / 13 / 24$, January.

Krugman, P. (2002) “The Disappearing Middle," New York Times, October 20.

Levi, M. (1988) Of Rule and Revenue (Berkeley, CA: University of California Press).

Lindert, K. E. Skoufias, and J. Shapiro (2006) Redistributing Income to the Poor and the Rich: Public Transfers in Latin America and the Caribbean, SP Discussion Paper No. 0605, World Bank. Lindert, P. (2004) Growing Public: Social Spending and Economic Growth since the Eighteenth Century (Cambridge: Cambridge University Press).

Lledo, V., A. Schneider, and M.Moore (2003) "Pro-poor Tax Reform in Latin America: A Critical Survey and Policy Recommendations," Institute for Development Studies, Sussex, UK, March.

Lopez-Calva, L. and N. Lustig (2010) “Explaining the Decline in Inequality in Latin America: Technological Change, Educational Upgrading, and Democracy," in L. Lopez-Calva and N. Lustig, eds., Declining Inequality in Latin America: A Decade of Progress? (Washington: The Brookings Institution), 1-22. Lora, E. (2012) Structural Reforms in Latin America: What has been Reformed and How to Measure It (Updated Version), IDB Working Paper IDB-WP-346.

Lora, E. and J. Fajardo (2011) Latin American Middle Classes: The Distance between Perception and Reality, IDB Working Paper Series No. IDB-WP-275, December. 
Lustig, N. and S. Higgins (2012) Fiscal Incidence, Fiscal Mobility and the Poor: A New Approach, Tulane Economics Working Paper Series 1202, April

Lustig, N., L. Lopez-Calva and E. Ortiz-Juarez (2012) Declining Inequality in Latin America in the 2000s: The Case of Argentina, Brazil, and Mexico, World Bank Policy Research Paper 6248, October. Lustig, N et al (2011) Fiscal Policy and Income Redistribution in Latin America: Challenging the Conventional Wisdom, Tulane Economics Working Paper Series 1124, October.

Mahon, J. (2011) "Tax Reform and Income Distribution in Latin America," in Blofeld, The Great Gap: Inequality and the Politics of Redistribution in Latin America. 313-347.

Mahon, J. (2012) Tax Incidence and Tax Reforms in Latin America, Woodrow Wilson Center Update on the Americas, Washington, November.

Martin, I., A. Malhotra and M. Prasad (2009) The New Fiscal Sociology (Cambridge University Press). Martinez-Vazquez, J. (2008) “Evaluating Mexico's Tax System," in B. Moreno-Dodson and Q. Wodon, eds., Public Finance for Poverty Reduction (Washington: World Bank).

McLure, C. (2001) "Globalization, Tax Rules and National Sovereignty," Bulletin of International Bureau of Fiscal Documentation, 55 (8): 328-342.

Mesa-Lago, C. (2008) Social Insurance (Pensions and Health), Labour Markets and Coverage in Latin America, Social Policy and Development Programme Paper Number 36, United Nations Research Institute for Social Development, August.

Mirrlees, J. et al. (2011) Tax by Design (Oxford: Oxford University Press).

Moller, L. (2012) Fiscal Policy in Colombia: Tapping its Potential for a More Equitable Society, World Bank Policy Research Paper 6092, June.

Morgan, J. and N. Kelly (2010) “Explaining Public Attitudes toward Fighting Inequality in Latin America," Poverty \& Public Policy, 2 (3): 79-111.

Musgrave, R. and P. Musgrave (1989) Public Finance in Theory and Practice, $5^{\text {th }}$ ed. (New York: McGrawHill).

North, D. and B. Weigast (1989) "Constitutions and Commitment: The Evolution of Institutions Governing Public Choice in Seventeenth Century England," Journal of Economic History, 49 (4): 803-832. OECD (2008) Growing Unequal? Income Distribution and Poverty in OECD Countries (Paris) OECD (2010) Tax Expenditures in OECD Countries (Paris). OECD (2012) Revenue Statistics (Paris). OECD (2012a) Revenue Statistics in Latin America (Paris). OECD (2012b) Taxing Wages 2011 (Paris) 
OECD (2012c) Education at a Glance 2012 (Paris)

Olson, M. (1965) The Logic of Collective Action (Cambridge, MA: Harvard University Press).

Pew Research Center (2012) The Lost Decade of the Middle Class. Available at http://www.pewsocialtrends.org/2012/08/22/the-lost-decade-of-the-middle-class/

Piketty, T. and E. Saez (2003) “Income Inequality in the United States: 1913-1998," Quarterly Journal of Economics, 118 (1): 1-39.

Piketty, T. and E. Saez (2013) Updated Data, Tbl.A1 \& A2 at http://elsa.berkeley.edu/ saez/TabFig 2011prel.xls.

Pinhanez, M. (2008) Reinventing VAT Collection: Industry Vertical Assessment, Revenue Increase, and Public Sector Reliability, Ph.D. dissertation, MIT, January.

Profeta, P. and S. Scabrosetti (2008) "Political Economy Issues of Taxation in Latin America," in L. Bernardi et al, eds., Tax Systems and Tax Reform in Latin America (Routledge), 63-76.

Reardon, S. (2011) "The Widening Academic Achievement Gap between the Rich and the Poor: New Evidence and Possible Explanations," in Wither Opportunity? Rising Inequality, Schools, and Children's Life Chances (New York: Russell Sage Foundation).

Roberts, K. (2012) The Politics of Inequality and Redistribution in Latin America's Post-Adjustment Era, UNU WIDER Working Paper No. 2012/08

Roemer, J. (2011) The Ideological and Political Roots of American Inequality, GINI Discussion Paper 8, March.

Sabates, R. and A. Schneider (2003) Taxation, Accountability and the Poor, Seminar Report, Institute of Development Studies, University of Sussex.

Sanchez, O. (2011) Mobilizing Resources in Latin America: The Political Economy of Tax Reform in Chile and Argentina. (New York: Palgrave Macmillan).

Shah, A. and J. Whalley (1991) "Tax Incidence Analysis of Developing Countries: An Alternative View," World Bank Economic Review, 5(3): 535-552.

Snydner, R. and D. Samuels (2001) “Devaluing the Vote in Latin America," Journal of Democracy, 12 (January): 146-59.

Social Security Administration (2012) Social Security Programs throughout the World: The Americas 2011. Washington.

Sokoloff, K.L. and Zolt, E.M. (2006) "Inequality and Taxation: Evidence from the Americas on how Inequality may Influence Tax Institutions," Tax Law Review, 59 (2): 167.

Steinmo, S. (1993) Taxation and Democracy (New Haven: Yale University Press). 
Taylor, M. et al. (1965) Fiscal Survey of Colombia (Baltimore: Johns Hopkins Press for the Organization of American States).

Tanzi, V. (1966) "Personal Income Taxation in Latin America: Obstacles and Possibilities," National Tax Journal, 19: 156-162.

Timmons, J. (2005) “The Fiscal Contract: States, Taxes, and Public Services," World Politics 57: 530-67.

Toder, E., B. Harris, and K. Lim (2009) "Distributional Effects of Tax Expenditures," Urban-Brookings Tax Policy Center.

Torche, F. and S. Spilerman (2008) "Household Wealth in Latin America," in J. Davies, ed., Personal Wealth in the Global Economy (Oxford: Oxford University Press). 150-176.

Torgler, B., Schaffner, M., and Macintyre, A. (2010) "Tax Compliance, Tax Morale, and Governance Quality," in Alm, J., Martínez-Vázquez, J., and Torgler, B., eds., Developing Alternative Frameworks for Explaining Tax Compliance (London: Routledge), 141-173.

U.S. Census Bureau (2012) Income, Poverty and Health Insurance Coverage in the United States: 2011. Washington.

Villela, L., A. Lemgruber and M. Jorratt (2010) Tax Expenditure Budgets: Concepts and Challenges for Implementation, IDB Working Paper Series No. IDB-WPS-131, April.

Wang, C. and K. Caminada (2011) Disentangling Income Inequality and the Redistributive Effect of Social Transfers and Taxes in 36 LIS Countries, MPRA Paper No. 32821, August.

Weisman, S. (2002) The Great Tax Wars (New York: Simon and Schuster).

WHO (2012) World Health Statistics 2012 (Geneva).

Wolff, E. (1996) Top Heavy: The Increasing Inequality of Wealth in America and What Can Be Done About It (New York, NY: New Press).

Wolff, E. (2012) "The Asset Price Meltdown and the Wealth of the Middle Class," The National Bureau of Economic Research. NBER Working Paper No. 18559.

Zolt, E. (2008) "Revenue Design and Taxation," in B. Moreno-Dodson and Q. Wodon, eds., Public Finance for Poverty Reduction: Concepts and Case Studies from Africa and Latin America (Washington: World Bank).

Zolt, E. (2013) “Inequality in America: Challenges for Tax and Spending Policies," draft paper. 